\title{
The income distribution in the UK: A picture of advantage and disadvantage
}

\author{
Stephen P. Jenkins
}

\section{Contents}

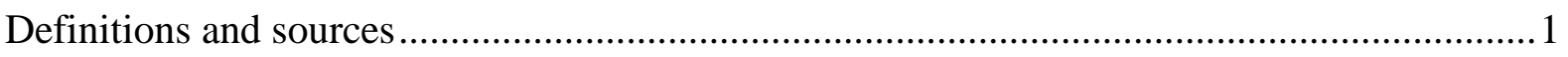

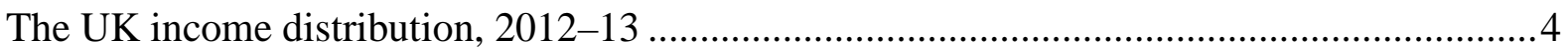

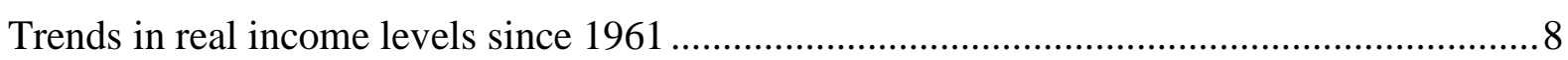

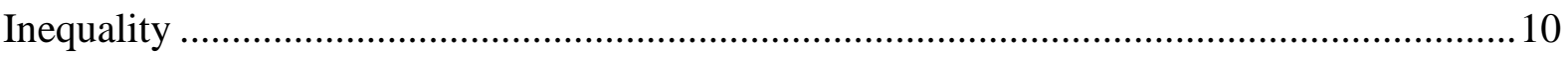

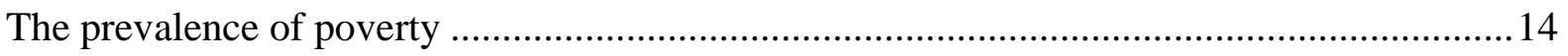

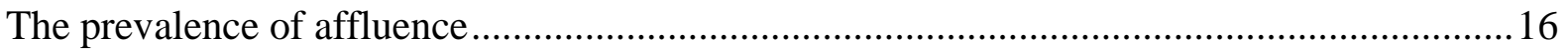

Income mobility and poverty dynamics.......................................................................... 19

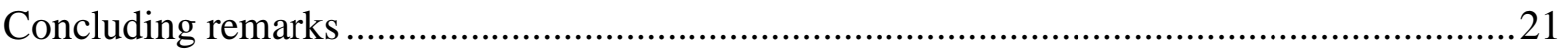

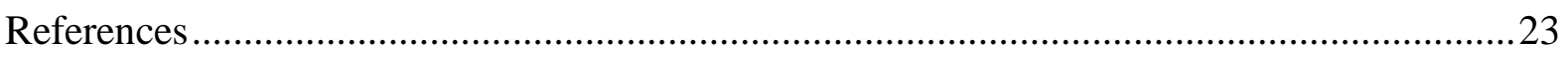

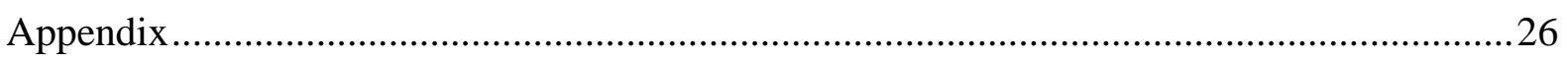

CASE/186

February 2015
Centre for Analysis of Social Exclusion London School of Economics Houghton Street London WC2A 2AE

CASE enquiries - tel: 02079556679 


\section{Centre for Analysis of Social Exclusion}

The Centre for Analysis of Social Exclusion (CASE) is a multi-disciplinary research centre based at the London School of Economics and Political Science (LSE), within the Suntory and Toyota International Centres for Economics and Related Disciplines (STICERD). Our focus is on exploration of different dimensions of social disadvantage, particularly from longitudinal and neighbourhood perspectives, and examination of the impact of public policy.

In addition to our discussion paper series (CASEpapers), we produce occasional summaries of our research in CASEbriefs, and reports from various conferences and activities in CASEreports. All these publications are available to download free from our website. Limited printed copies are available on request.

For further information on the work of the Centre, please contact the Centre Manager, Jane Dickson, on:

Telephone: UK+20 79556679

Fax: $\quad$ UK+20 79556951

Email: j.dickson@lse.ac.uk

Web site: http://sticerd.lse.ac.uk/case

(C) Stephen P Jenkins

All rights reserved. Short sections of text, not to exceed two paragraphs, may be quoted without explicit permission provided that full credit, including (๑) notice, is given to the source. 


\section{Editorial note and acknowledgements}

Stephen Jenkins is a Professor of Economic and Social Policy in the Department of Social Policy at the London School of Economics and a CASE associate. He is also a Research Fellow at IZA (Bonn) and a Visiting Professor at the University of Essex.

This paper is to appear as a chapter in Social Advantage and Disadvantage (H. Dean and L. Platt, eds.), OUP, 2015. I wish to thank Tony Atkinson, John Hills, Rob Joyce, Lucinda Platt, and other contributors to the volume for their comments and suggestions on a preliminary draft. For comments and advice on my use of HBAI and SPI data, I thank Nancy Singh and Peter Matejic (DWP) and Jeremy Reuben (HMRC). This research was partially supported by core funding of the Research Centre on Micro-Social Change at the Institute for Social and Economic Research by the University of Essex and the UK Economic and Social Research Council (award ES/L0009153).

\section{Abstract}

This paper describes the UK income distribution and how it has evolved over the last 50 years. It also includes some comparisons with the income distributions of other rich countries. Multiple perspectives on the distribution are provided: there is evidence about real income levels and inequality, and the prevalence of affluence and of poverty.

Key words: Inequality, poverty, affluence, income distribution, United Kingdom

JEL classification: D31, I32

Correspondence

Stephen P. Jenkins, Department of Social Policy, London School of Economics, Houghton Street, London WC2A 2AE. Email: s.jenkins@lse.ac.uk 
This paper provides a picture of advantage and disadvantage in Britain using the lens provided by the most commonly-used measure of individuals' material well-being, the income of the household to which they belong. Income is not the only indicator that may be used to characterise whether an individual is badly-off or well-off or to summarise the extent of poverty and affluence in a country overall. Complementary perspectives are provided by information about social inclusion and exclusion measured by a set of material deprivation indicators, individuals' capabilities and functionings, whether their human rights are realised, or their social class. Nonetheless, income-based measures are particularly important. In a modern-day mixed economy such as the UK's, individuals' money income is the preeminent measure of their command over resources. For this reason, income is the principal focus of the statistics used to assess social progress in the UK and other rich countries. The strengths and weaknesses of using income to measure material living standards are not reviewed here. Instead, the aim of this paper is to describe the distribution of income in the UK today, documenting how it has changed over the last 50 years and how it compares with those of international comparators such as other European and OECD countries.

The paper provides multiple perspectives on the income distribution. I discuss evidence about the real income levels and inequality, as well as the prevalence of poverty and of affluence. In the concluding section, I reflect on some of the issues raised by the evidence. First, however, I need to explain the definitions and sources used in the paper.

\section{Definitions and sources}

Throughout the paper (with an exception discussed below), an individual's 'income' is the equivalised net income of the household to which he or she belongs. This is equal to the total money income received by all household members from all sources minus income taxes and national insurance contributions paid and some other deductions, deflated by an equivalence scale factor that adjusts for differences in household size and composition, and adjusted using a price index to take account of inflation.

The specific money income sources included in the net income definition are those used by the Department for Work and Pensions' (DWP's) Households Below Average Income (HBAI) statistics are shown in Table 1. (These statistics are the UK's official statistics about the income distribution among persons.) Incomes are reported on a weekly basis. If someone reports earnings or other receipts over a longer period (e.g. an annual or monthly salary), the amount is converted to a weekly-equivalent amount pro rata. 
Table 1: The definition and sources of net household income: receipts and deductions

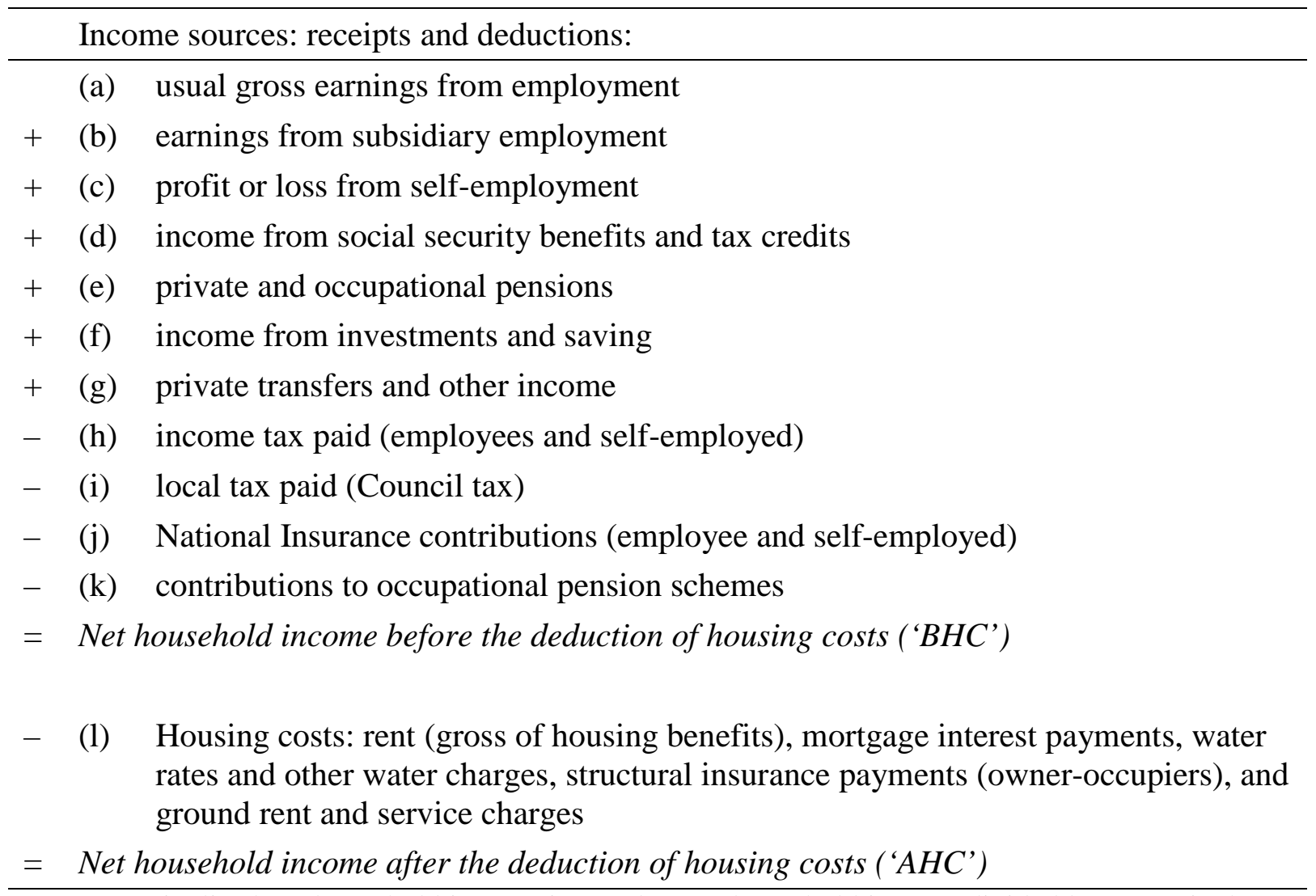

Notes: Equivalised net household income is equal to net household income divided by an equivalence scale (to adjust for differences in household size and composition). Incomes in different years are adjusted by a year-specific price index to express them in constant purchasing power terms. See main text for further details.

Observe the distinction between net income before the deduction of housing costs (net income BHC) and net income after the deduction of housing costs (net income AHC). The HBAI statistics report income distribution estimates based on both definitions; the BHC definition is the one that is used by international organisations such as Eurostat and the OECD, and international data providers such as the Luxembourg Income Study, and is consistent with the recommendations of bodies such as the Expert Group on Household Income Statistics (2001). For this reason, my discussion focuses on distributions based on the net income BHC definition, but I also refer to AHC distributions measures where they lead to different conclusions about distributional trends. For further discussion of BHC and AHC measures, see Johnson and Webb (1992).

In order to compare real living standards over time in constant purchasing power terms, taking account of the fact that $£ 1$ in 1990 is worth more than a $£ 1$ in 2000 because of inflation, all incomes are adjusted using a price index and expressed in the prices of a particular year (financial year 2012-13 below). This assumes that all groups in society experience same rate of price inflation. Evidence about differences is provided by Flower and Wales (2014). 
Equivalisation produces a measure of real living standards that is comparable across households in a given year. A money income of $£ 500$ per week (say) leads to higher living standards for a single householder than a childless married couple or a family of four. Looking at per capita income (total income divided by household size) would be one way of taking account of this issue, but this adjustment would not take account of potential economies of scale in the provision of household goods and services such as space, heat and light, food preparation and purchase, and so on. Two can live almost as cheaply as one. According to HBAI definitions, a net household income (BHC) of $£ 500$ per week for a married couple is equivalent in living standards terms to $£ 750$ pounds per week for a single householder ( $£ 500$ is two-thirds not one-half of $£ 750$ ). Children add to household needs, of course, but not as much as an additional adult. According to HBAI definitions, a net household income of $£ 500$ per week corresponds to $£ 417$ per week in living standards' terms for a married couple with one child (aged less than 14 years), or £357 per week if there are two children. These adjustments are characterised by the so-called modified-OECD equivalence scale: see DWP (2014b) for further details and note the slightly different adjustment applied to AHC incomes.

The final step in defining the income distribution is the assumption that the household income total is shared equally within each household, so that each individual is attributed with the equivalised income of the household to which he or she belongs. Individuals without income of their own, such as children, are assumed to benefit from income transfers by other individuals within the household. Supposing that complete income sharing is the universal rule is undoubtedly inaccurate, but it is also difficult to imagine what other assumptions would be more appropriate to implement. The equal-sharing assumption is widely adopted by analysts and statistical agencies around the world, not only in the UK. The assumption and alternatives are analysed by Jenkins (1991). There is also the issue of whether the aggregate 'income unit' should be taken to be the household, or the more narrowly defined nuclear family (or 'benefit unit') as in the UK's pre-HBAI low income statistics. See also National Equality Panel (2010), which provides information about the distribution of 'individual incomes' - the distribution arising were each adult to benefit only from the income that he or she received.

Estimates of income distributions characterised using the definitions outlined are derived in the UK using data from the Family Resources Survey, a large household survey that has been running since the early 1990s, with data for earlier years (back to 1961) coming from the Family Expenditure Survey. At several points below, I supplement the survey-based estimates with information derived from income tax data from Her Majesty's Revenue and Customs (HMRC). For assessing advantage, tax data have benefits compared with household surveys because there is better coverage of the top of the income distribution and arguably measurement error may be less. In addition, sample sizes are much larger and some data series go back to the beginning of last century. On the other hand, the distributional definitions are less satisfactory because they are constrained by what is relevant to administer the income tax system: they refer to gross taxable (or after-tax) income of tax units (which in the UK refer to 
individuals since 1990). And the most detailed data (from the Survey of Personal Incomes) refer to taxpayers rather than to the full population.

The final point to note about definitions is that this paper is about income. Income is not the same as 'consumption', which refers to the resources actually enjoyed by households (measured in terms of their spending) rather than their potential command over resources. Income is arguably a better indicator of someone's economic power. (For comparisons of distributions of consumption expenditure and income in the UK, see Brewer and O’Dea (2012).) Also, income and consumption each refer to flows per period, and should be distinguished from the stock of financial assets at a particular point in time, i.e. wealth.

\section{The UK income distribution, 2012-13}

The UK's income distribution in 2012-13 (BHC definition) is pictured in Figure 1. (See DWP 2014a for the corresponding AHC picture.) The chart shows the numbers of individuals with (equivalised) incomes in each $£ 10$ band between zero and $£ 1000$ per week. The stripes classify individuals according to where they stand in the income parade that orders them from poorest to richest. The poorest tenth (decile group 1) are on the left and the richest tenth (decile group 10) on the right, with the other eight decile groups in between. The frequency distribution is not bell-shaped as with a Normal distribution; rather, it is skewed with a long right-hand tail. Not all of the very richest individuals can be shown on the chart: the income of the person in the middle of richest tenth (the $95^{\text {th }}$ percentile) is $£ 1,117$ per week, and there are around 2.93 million people with incomes above this amount.

The greatest concentration of individuals along the income range is between about $£ 250$ and $£ 400$ per week (the frequencies are greatest, and the stripes narrowest). The middle income (the median or 50th percentile) is $£ 440$ per week, which is only $82 \%$ of the average (mean) income of $£ 535$ per week. The person with average income is found some two-thirds of the way along the income parade and hence not particularly representative of 'middle incomes'. Also shown in Figure 1 is the value of the mostcommonly used poverty line in the UK and Europe (60 per cent of median income). The threshold was £264 per week in 2012-13, and it can be seen that between 15 per cent and 20 per cent of individuals were income-poor in 2012-13. (More detail about the prevalence of disadvantage is provided later.) Finally, observe the perhaps surprisingly large number of individuals with an income between $£ 0$ and $£ 10$ per week. Although this refers to fewer than 1 per cent of the UK population, the number raises questions about the accuracy of measurement of very low incomes. On this, see Brewer et al. (2009). 
Figure 1: The UK income distribution, 2012-13

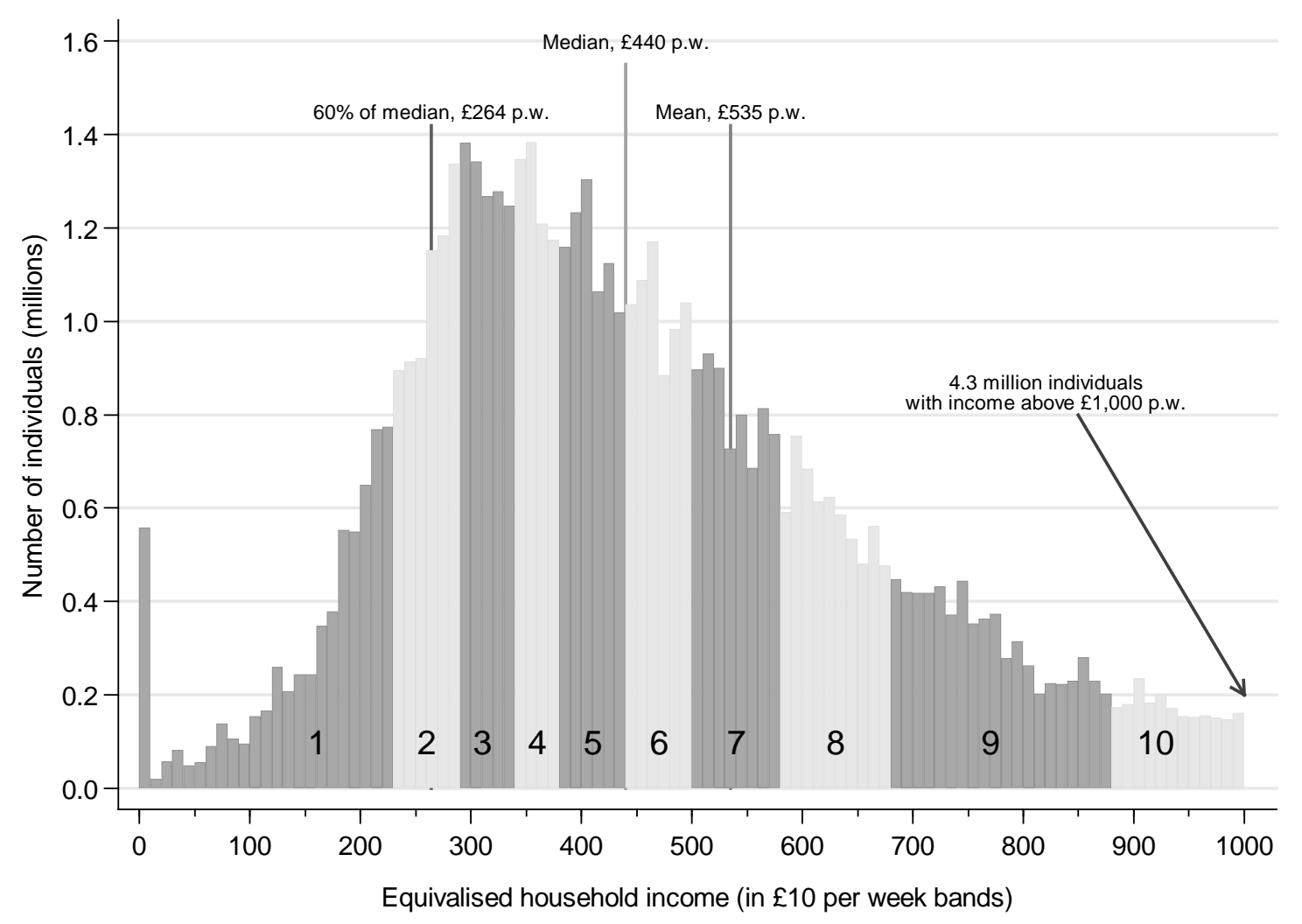

Notes: Graph drawn by the author using data from the spreadsheet accompanying Chart 2.4 (BHC) in DWP (2014a).

The HBAI data also tell us who the poorest and richest individuals were in 2012-13. Table 2 shows the composition of the poorest tenth and the richest tenth, using a range of subgroup definitions that classify individuals according to their or their family's characteristics.

Table 2 shows, for example, that adult men and women and children are represented in the poorest tenth in proportion to their numbers in the population as a whole, but men are over-represented in the richest tenth ( 45 per cent compared to 38 per cent) and children are under-represented (16 per cent compared with 21 per cent). 
Table 2: Composition of the poorest and richest tenths of the 2012-13 income distribution, by subgroup

\begin{tabular}{|c|c|c|c|}
\hline \multirow[b]{2}{*}{ Subgroup } & \multicolumn{3}{|c|}{ Subgroup share (\%) of: } \\
\hline & Poorest tenth & Richest tenth & Population \\
\hline \multicolumn{4}{|l|}{ Sex and adulthood } \\
\hline Adult man & 38.6 & 45.0 & 38.3 \\
\hline Adult woman & 39.5 & 39.6 & 40.5 \\
\hline Child & 21.9 & 15.5 & 21.2 \\
\hline \multicolumn{4}{|l|}{ Family type } \\
\hline Pensioner couple & 10.3 & 12.3 & 13.6 \\
\hline Single male pensioner & 1.9 & 1.3 & 1.9 \\
\hline Single female pensioner & 7.5 & 1.7 & 5.2 \\
\hline Couple with children & 32.4 & 32.6 & 34.9 \\
\hline Single with children & 10.1 & 1.0 & 8.0 \\
\hline Couple without children & 13.1 & 35.3 & 18.4 \\
\hline Single male without children & 16.0 & 10.9 & 10.8 \\
\hline Single female without children & 8.6 & 5.1 & 7.2 \\
\hline \multicolumn{4}{|l|}{ Economic status } \\
\hline One or more self employed & 14.8 & 18.1 & 9.8 \\
\hline Single/couple all in full time work & 4.9 & 45.7 & 26.2 \\
\hline Couple/one in full time, one part time & 2.6 & 13.2 & 13.1 \\
\hline Couple, one full time one not working & 8.3 & 8.2 & 10.5 \\
\hline No full time, one or more part time worker & 15.0 & 5.2 & 10.1 \\
\hline Workless, head or spouse aged 60 or over & 20.7 & 6.7 & 17.3 \\
\hline Workless head or spouse unemployed & 14.6 & 0.7 & 3.8 \\
\hline Workless, other inactive & 19.2 & 2.3 & 9.3 \\
\hline \multicolumn{4}{|l|}{ Region } \\
\hline Rest of the UK & 75.3 & 55.4 & 73.2 \\
\hline London and South East & 24.7 & 44.6 & 26.8 \\
\hline
\end{tabular}

Individuals from pensioner couples, and couples with and without children families, are under-represented in the poorest tenth relative to their numbers in the population as a whole (see the second panel). Over-represented are single female pensioners, individuals in lone parent families, and childless singles. In the richest tenth, almost all groups are under-represented, with one striking exception. Childless couples are substantially over-represented, and account for more than one-third of the richest tenth though they comprise only 18 per cent of the population. 
The third panel of Table 2 shows that over- and under-representation at the top and bottom is closely associated with participation in paid employment. For example, individuals in benefit units in which all adults are in full-time work are substantially under-represented in the poorest tenth ( 5 per cent compared with their population proportion of 26 per cent) and substantially over-represented in the richest tenth (46 per cent compared to 26 per cent). The situation is reversed for non-pensioner families in which the head or spouse is unemployed: individuals in this group comprise almost 4 per cent of the population, but nearly 15 per cent of the poorest tenth and less than 1 per cent of the richest tenth. By contrast, individuals belonging to a family with selfemployment income are over-represented in both the poorest and the richest tenths. The final panel shows that, although there is no southern tilt to the composition of the poorest tenth, people living in London and the South East form a substantially greater fraction of the richest tenth than would be expected from their relative numbers in the country as a whole (45 per cent compared to 27 per cent).

These patterns of subgroup over- and under-representation at the bottom and the top reflect the distribution of income within each of the various subgroups. These subgroup distributions are summarised in Figure 2 using boxplots. The left and right hand ends of the box for each group show the $25^{\text {th }}$ and $75^{\text {th }}$ percentiles for that group (half the group have incomes within this range). The end of the 'whisker' extending left from the box shows the $10^{\text {th }}$ percentile for the subgroup, whereas the end of the right whisker shows the $90^{\text {th }}$ percentile (80 per cent of the subgroup have incomes within the range spanned by the box and whiskers). Subgroup median income (50 ${ }^{\text {th }}$ percentile) is shown by the black bar within the box. The vertical dashed lines show the $10^{\text {th }}, 50^{\text {th }}$, and $90^{\text {th }}$ percentiles for the population as a whole ('all individuals'; as also shown in Figure 1), and hence demarcate the thresholds used to define income groups in Table 2.

The boxplots illustrate both subgroup income levels and the range of subgroup incomes. Individuals in families with children, and dependent children in particular, tend to have lower incomes than other groups. Although the distribution among all women closely mimics that of the population as a whole, there are groups of woman who are clearly worse off: look at the plots for single female pensioners and the 'single with children' group (most of whom are in families headed by lone mothers). In contrast, childless couples have relatively high incomes: almost three-quarters of this group have an income above the population median.

The third panel highlights the importance of paid employment for income, with distributions further to the left (lower) as the degree of participation falls. For example, contrast individuals in benefit units in which all individuals are in full-time work (more than 75 per cent have an income above the population median) with individuals in a family with an unemployed head or spouse (almost 90 per cent have an income below the population median). Families with self-employed members are a distinctive case because of the relatively high prevalence of both low incomes and (especially) very high incomes. Substantially more than one-tenth of this group have an income placing them in the richest 5 per cent of the population as a whole. 
Figure 2: Income distributions for population subgroups, UK, 2012-13

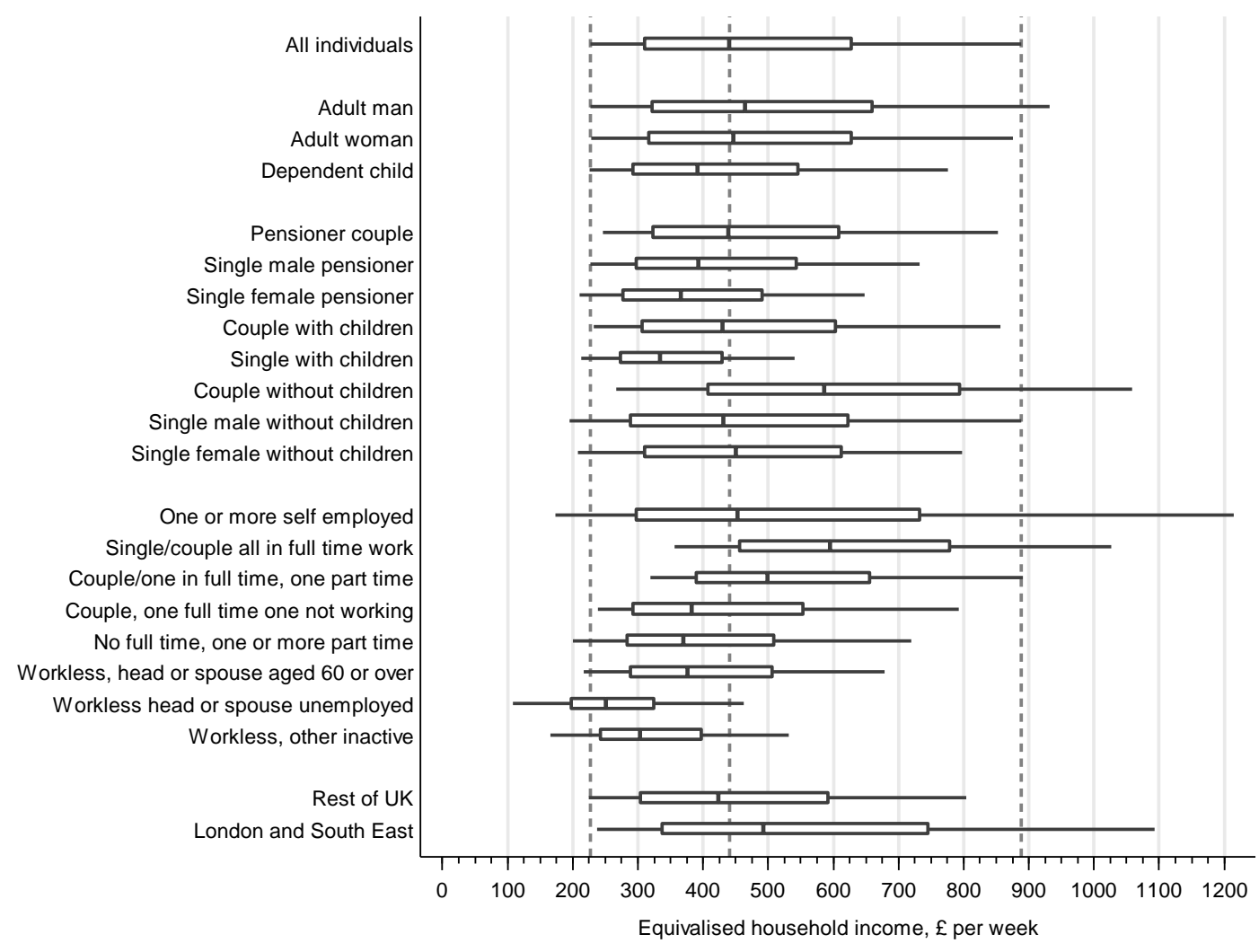

Notes: Each subgroup's boxplot shows the 10th, 25th, 50th, 75th, and 90th percentiles for the relevant subgroup: see the main text. The vertical dashed lines show the 10th, 50th, and 90th percentiles for the population as a whole ('all individuals'). Graph drawn by the author using data from the spreadsheet accompanying Belfield et al. (2014) - see IFS (2014) - for 'all individuals' and his calculations using data from the public-use file of unit-record HBAI data (accompanying DWP 2014a) for all other groups. Incomes in the public-use HBAI file are rounded to the nearest pound.

The fourth panel of Figure 2 highlights the relative affluence of most individuals living in London and the South East. The person at the $75^{\text {th }}$ percentile for this region's distribution is clearly within the richest twentieth of the population ranked by income (see Figure 1), whereas the corresponding person in the distribution for the rest of the UK is on the borders of the richest seventh and eighth tenths nationally. More than 10 per cent of individuals living in London and the South East are in the richest 5 per cent of the population.

\section{Trends in real income levels since 1961}

Conclusions about the extent to which real incomes have been rising depend a lot on how long one looks back and which part of the income distribution one considers. See Figure 3 , which shows income levels at the $10^{\text {th }}, 50^{\text {th }}$, and $90^{\text {th }}$ percentiles, as well as the mean. Grey stripes demarcate recessions. (Appendix Table A1 summarises the trends shown in the graph, providing income growth rates for the period as a whole and subperiods within it.) 
Looking at the fifty-year period since 1961, the general picture is of rising incomes for all, punctuated by short periods of slow or negative growth accompanying recessions. The sharpest deviation from trend is the period after 2007, i.e. following the most recent recession, though it should be noted that a slowing in income growth is also apparent earlier - from the beginning of the 2000s - and there was also a period of little growth in the early-1990s.

Figure 3: Trends in real income levels since 1961

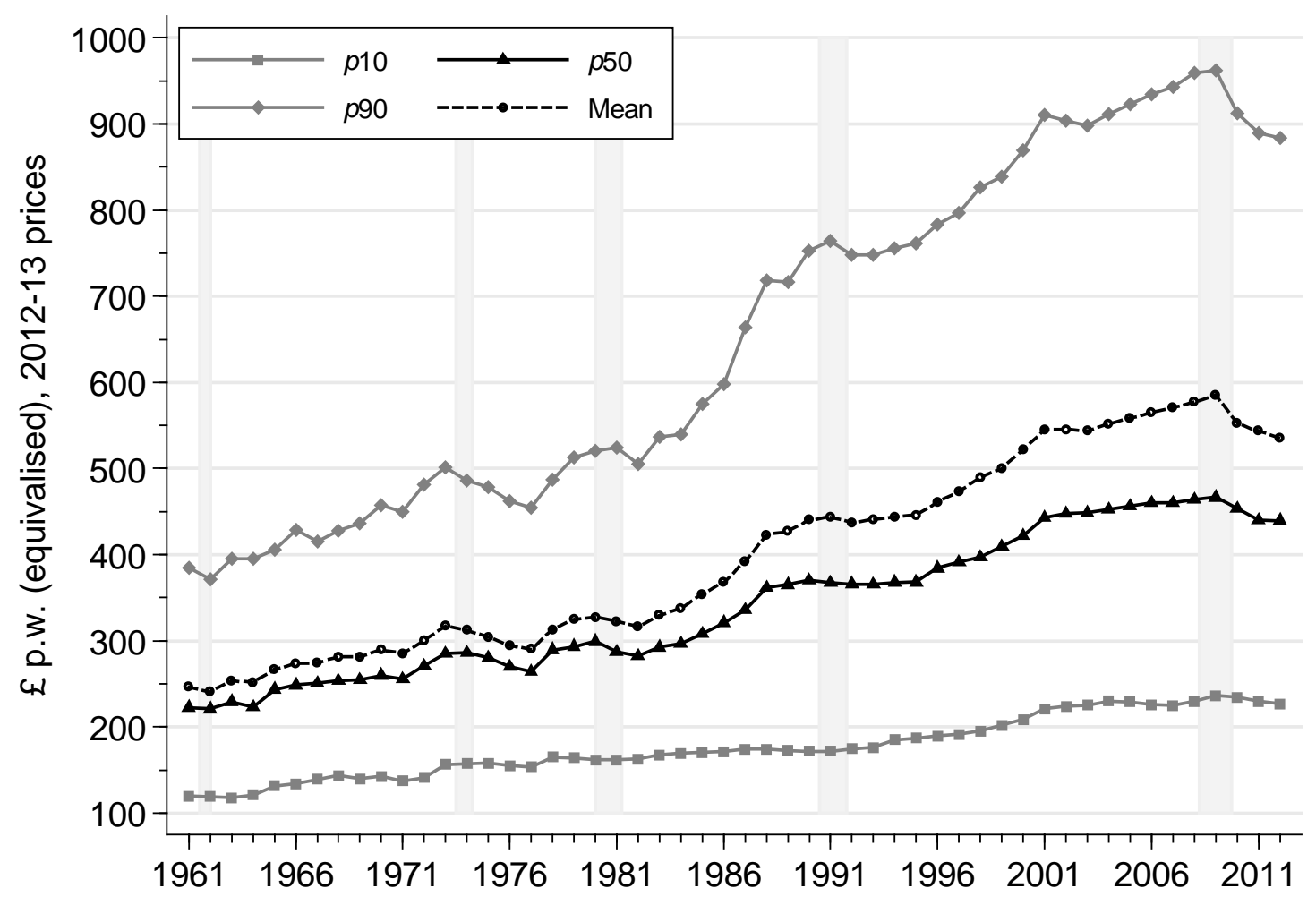

Notes: Graph drawn by the author using data from the spreadsheet accompanying Belfield et al. (2014) - see IFS (2014). The grey strips identify periods with at least two consecutive quarters of negative real GDP growth. p10, p50, and p90 are the 10th percentile, 50th percentile (median), and 90th percentile, respectively. The data refer to financial years from 1994 onwards, and the estimates to the UK from 2002-03 and Great Britain in earlier years. See Appendix Table A1 for numerical estimates of growth rates for the period as a whole as well as subperiods.

Also striking is the differential income growth across the income range: growth has been greatest at the top and small at the bottom. Over the five decades between 19612012, the $90^{\text {th }}$ percentile grew by 130 per cent (equivalent to a rate of around $1.6 \%$ per year), the median grew by 97 per cent and the $10^{\text {th }}$ percentile by 89 per cent (equivalent to $1.3 \%$ per year in both cases). Although income falls were greatest for the richest groups between 2007 and 2012 (the $90^{\text {th }}$ percentile fell by $6.2 \%$ per year; the $10^{\text {th }}$ percentile by $0.2 \%$ per year), this reversal of fortunes is small if compared with the longer-term trend of growing real incomes at the top. 
The fall in real incomes across the income distribution after the most recent recession is not as dramatic as the squeeze on real wages reported by Gregg, Machin, and Fernández-Salgado (2014), particularly at the bottom of the distribution. Several factors are likely to explain this. For example, a fall in real wages of one household member might be offset by more work hours by another household member. Household composition may itself change: e.g. young people may be more likely to live with their parents or share with others. And the safety net income provided by benefits and tax credits has continued to provide a real income floor.

\section{Inequality}

The growing gap between top and bottom incomes shown in Figure 3 implies growth in income inequality. Inequality is summarised directly in Figure 4, in terms of the ratio of the $90^{\text {th }}$ to the $10^{\text {th }}$ percentile $(p 90 / p 10)$ and the Gini coefficient. Regardless of which index is used, the rise in inequality over the last fifty years has been substantial: between 1961 and 2011, the Gini rose by almost one-third and p90/p10 by around one half. Most of that inequality growth occurred in the 1980s. Clearly this is an exceptional period: within both the preceding two decades and the subsequent two, the two inequality series are relatively flat, with relatively small year-on-year changes. Nonetheless, there is a small but distinct decline in p90/p10 after 1991 that is not apparent in the Gini coefficient. This reflects changes in the distribution of incomes below the median to which the Gini is not as sensitive (graphs not shown).

Inequality declined during the most recent recession, reflecting the larger income falls for those at the top compared to those at the bottom, but even this inequality decline is relatively small and a bit smaller than the decline in the early- to mid-1970s (when inequality was much lower). 
Figure 4: Income inequality since 1961

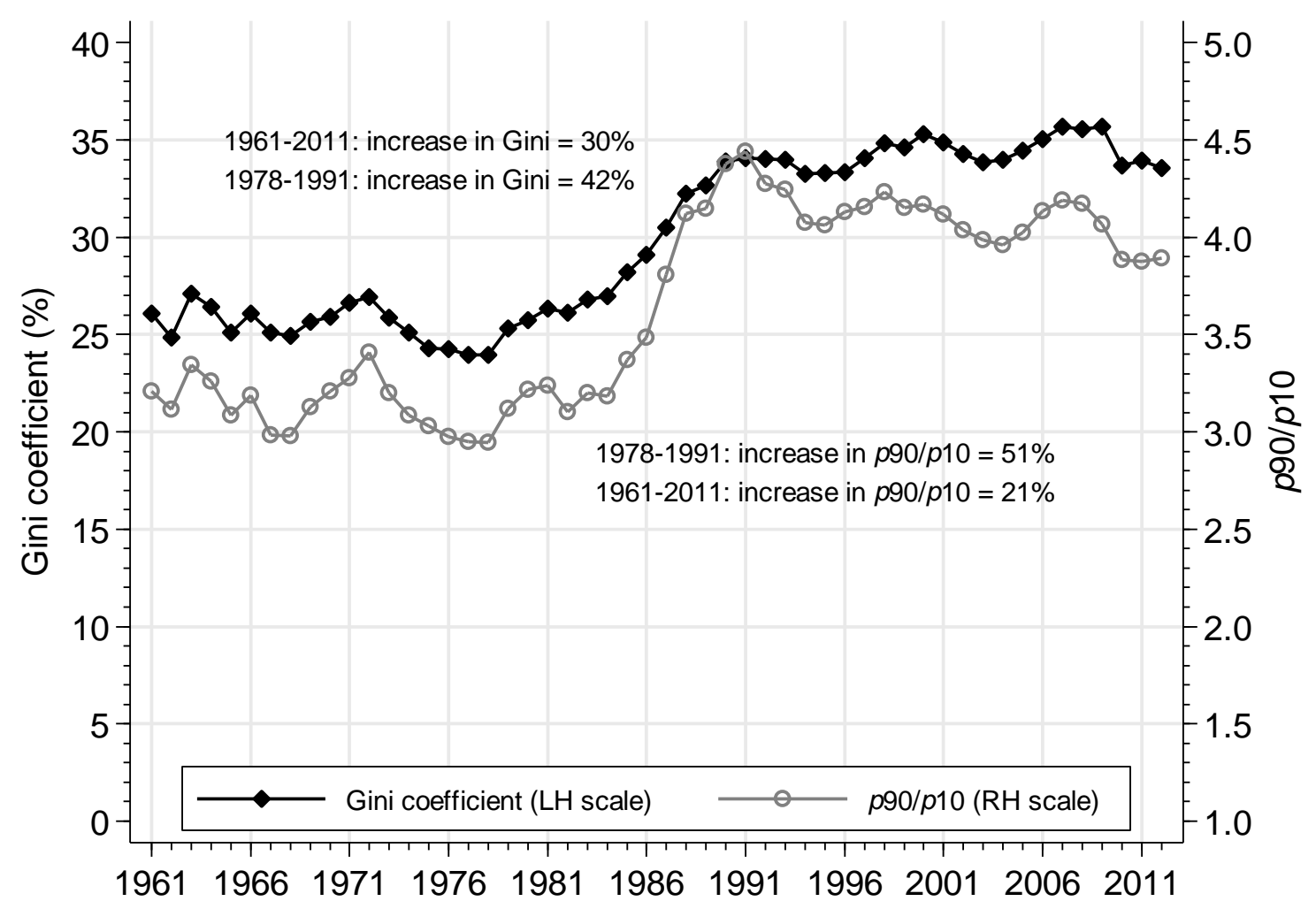

Notes: Graph drawn by the author using data from the spreadsheet accompanying Belfield et al. (2014) - see IFS (2014). The data refer to financial years from 1994 onwards, and the estimates to the UK from 2002-03 and Great Britain in earlier years.

The level and trend in inequality in the UK is compared with those of 20 other OECD countries in Figure 5 (the distributional definitions are similar to those employed in previous charts). Countries are grouped according to whether inequality fell, increased, or remained much the same, between the mid-1980s and 2011-12, with inequality measured using the Gini coefficient. The UK's estimate for 2011-12, around 0.34 , places it just above the average in the 21-country ranking (the OECD Gini was around 0.32) but, if middle-income countries such as Mexico and Turkey are excluded, the UK shows up more clearly as a high-inequality country relative to other rich countries. Inequality in the UK is not as great as in the USA, however.

Figure 5 also shows that the majority of OECD countries experienced inequality growth over the last quarter century; it was not only the UK. Moreover, the magnitude of the increase was greater in a number of other countries besides the UK, several of which were relatively low-inequality countries in the mid-1980s (Finland, Sweden, and Germany). (Be aware that the inequality-increase rankings are contingent on the period considered: the increase in the UK during the 1980s, shown earlier, was substantial by cross-national standards.) Nonetheless, the chart also demonstrates that an increase in inequality is not inevitable: inequality changed hardly at all in three EU15 nations (France, the Netherlands, and Belgium). 
Figure 5: Income inequality in 21 OECD countries: mid-1980s and 2011/12

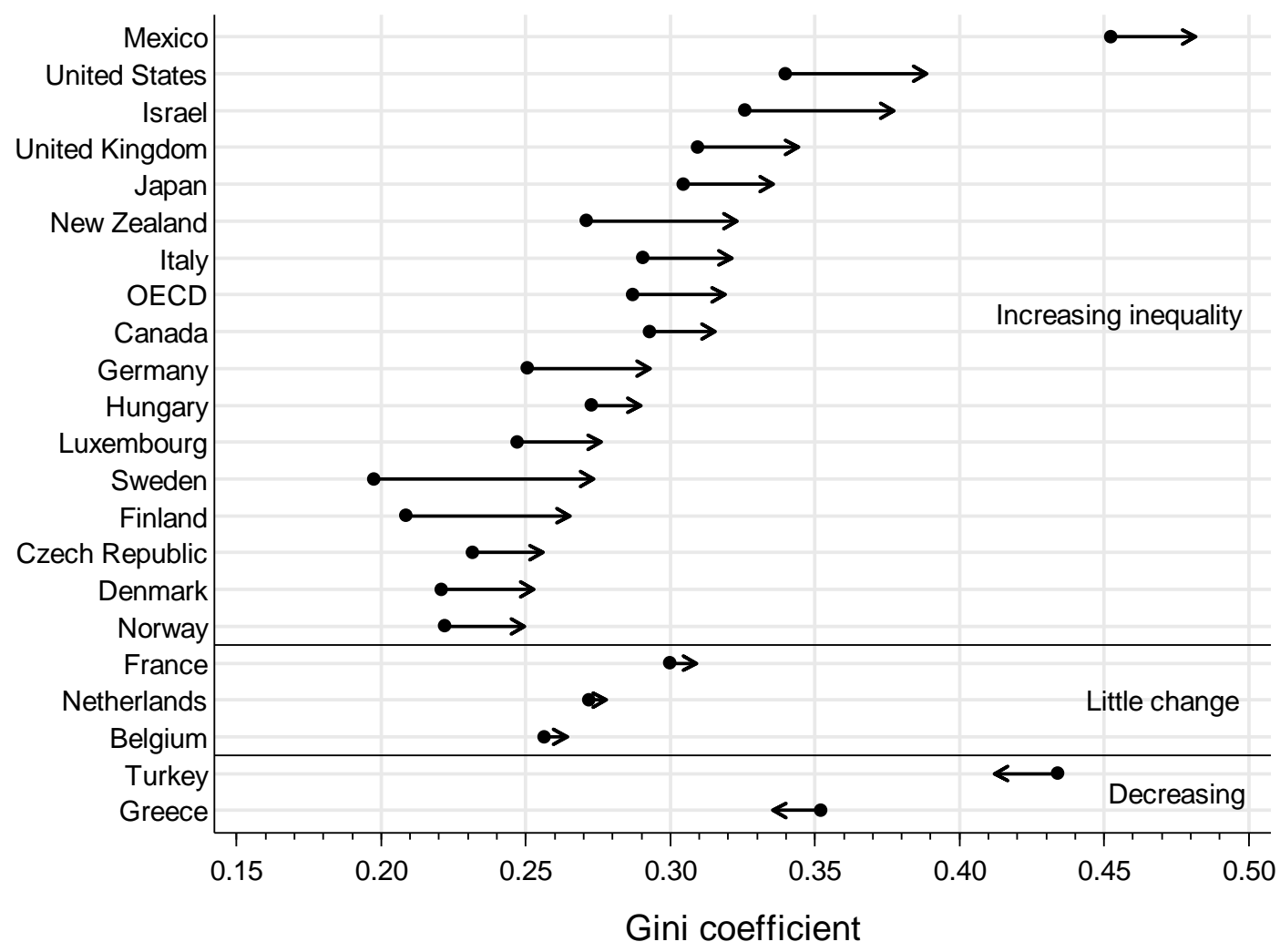

Notes: Graph drawn by the author using data in the spreadsheet accompanying OECD (2014, Figure 1). This source provides details of the actual years compared for each country. 'Little change' in inequality refers to changes of less than 1.5 percentage points. Countries are ordered within each panel by their Gini coefficient for 2011/12. Income is household disposable income adjusted for household size.

If the comparison is with the EU-15 as a whole, income inequality in the UK has been greater for most of the last decade but in 2013 was about the same. At the beginning of the 2000s, the UK Gini was around four percentage points greater than the EU-15 Gini, but the former subsequently declined and the latter increased. In 2013, both Ginis were around 0.30: see Appendix Figure A2. (The UK estimates differ slightly from those shown in Figure 4 because they are derived from different data sources.)

Much of the trend in UK inequality has been driven by what happens to top incomes and yet estimates derived from household surveys (such as shown in Figure 3) may miss what is going on at the very top of the income distribution. In contrast, income tax data have better coverage of the richest incomes and provide estimates for a much longer period.

Estimates of top income shares derived from tax data are shown in Figure 6 and go back almost a century. The series shown in black shows trends in the share of total income held by the richest $10 \%, 1 \%$, and $0.1 \%$. The share of the top $10 \%$ in 2011 , around $40 \%$, is much the same as it was just after World War I. Over the subsequent 
six decades, the share declined by around 10 percentage points, but increased steadily thereafter albeit with a pause associated with the most recent recession. A U-shaped trend is also apparent for the shares of the top $1 \%$ and top $0.1 \%$, though the inequality increases since the late 1970s have not taken the shares back to WWI levels. Also shown are trends in the shares of nearly-top groups variously defined (the series in grey) and, intriguingly, there is no distinct U-shape to these series as there is for the others. This implies that the U-shape trends for top income shares are being driven by what is happening to the very richest group (the richest $0.1 \%$ in this case).

Figure 6: Top income shares (\%) in the UK over the last 100 years

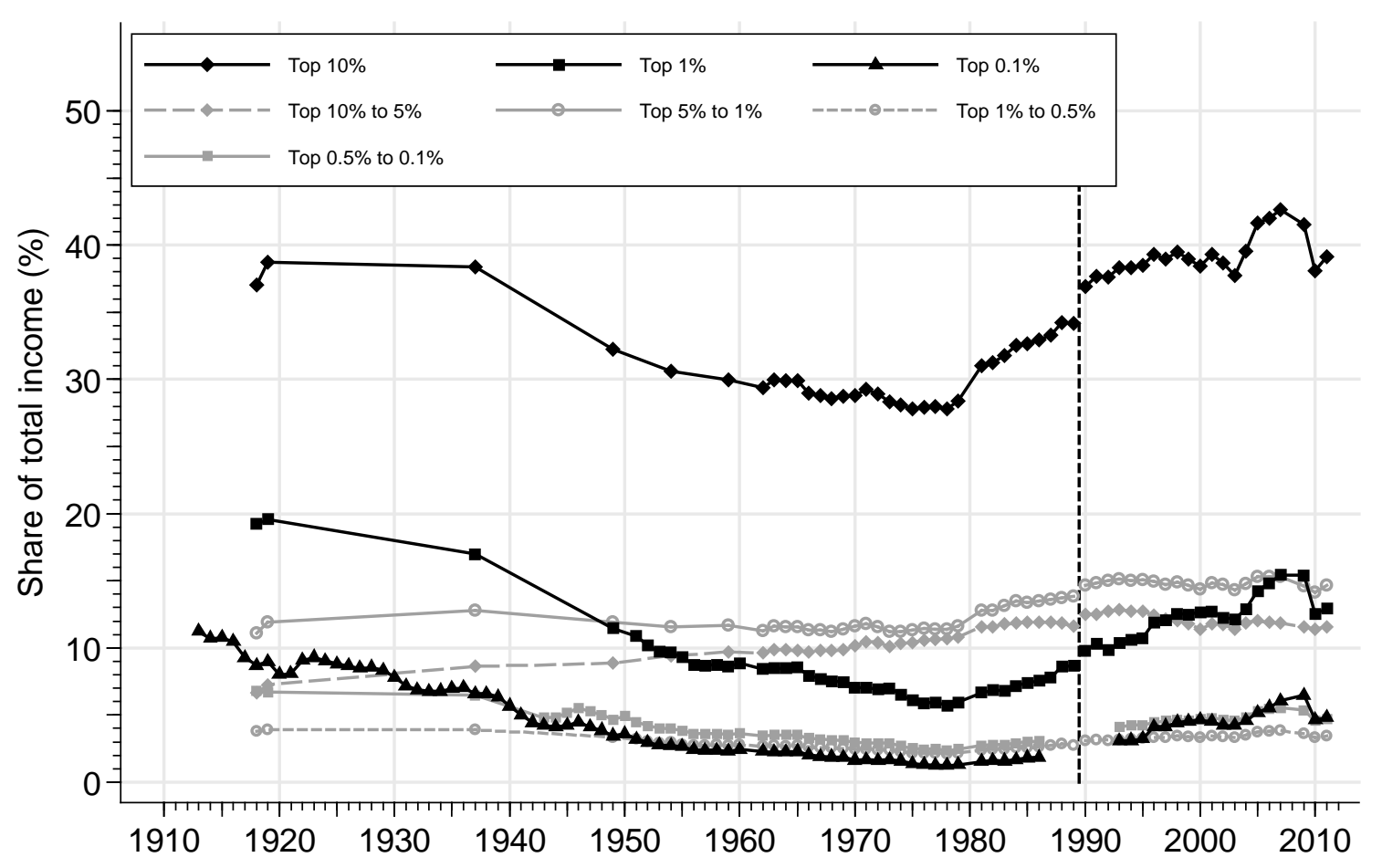

Notes: Graph drawn by the author using data from the World Top Incomes Database (Alvaredo et al. 2014). The vertical dashed line marks the change in the definition of the tax unit from the family to the individual in 1990.

Thus, even though inequality in the UK has not grown much over the last two decades according to HBAI-based measures (Figure 4), the evidence from tax data about top income shares suggests a continuing and substantial rise in inequality over this period. Put differently, recent inequality trends are a story of greater differentials that are driven by increasing advantage. The UK experience is similar to that of other 'Anglo' countries such as the USA, but is less apparent in other countries such as Germany, and especially France where the long inequality decline has not been followed by a large inequality rise. See Appendix Figure A3 and, for more extensive cross-national comparisons, Atkinson, Piketty, and Saez (2011). 


\section{The prevalence of poverty}

Historically, social policy has been particularly concerned with the prevalence of poverty rather than other aspects of income distribution. Trends in income poverty are the subject of this section.

A fundamental issue is how the income cut-off that differentiates poor people from non-poor people should be defined. The threshold most commonly employed by the European Union, and the UK as well, is $60 \%$ of contemporary national median income. The 'contemporary national' tags mean that the poverty line varies from one year to the next (as median income changes), and differs in real terms across countries (UK median income is substantially greater than Romanian median income, for instance).

This 'relative poverty' definition implements - in a particular way - the idea that '[p]eople are said to be living in poverty if their income and resources are so inadequate as to preclude them from having a standard of living considered acceptable in the society in which they live' (Council of the European Union, 2004: 8). Although a relative poverty definition has many conceptual attractions, it can lead to implausible estimates in times of economic boom or sharp recession when the median income itself can change substantially (Jenkins et al., 2013: chapter 1).

This suggests that more 'absolute' poverty threshold definitions be employed in tandem with relative ones. However, few would seriously argue that a fully absolute definition - a real income cut-off that is fixed over time and the same for all countries - is appropriate for rich countries such as the UK. More commonly used for assessing trends are 'anchored' poverty lines. The idea is that poverty in the current year and previous years be assessed using a threshold that is fixed at the value of the relative poverty line for an earlier (but relatively recent) year. Thus, DWP HBAI publications supplement estimates based on a cut-off of $60 \%$ of contemporary national median income with estimates based on a threshold equal to $60 \%$ of $2010-11$ median income or (previously) the 1998-99 median. The Institute for Fiscal Studies has provided data on anchored poverty rates using the 1996-97 median, which I use. Estimates of poverty rates for the last fifty years based on the relative and two anchored thresholds are shown in Figure 7.

Clearly, the choice of low-income cut-off makes a substantial difference to estimates of both the prevalence of poverty in recent years, and its trend over time. Using the relative poverty line based on contemporary medians, the poverty rate fluctuated between around 12 per cent and 15 per cent in the twenty years after 1961, then increased sharply to reach more than 20 per cent in the late-1980s, and has been gradually declining since the early 1990s. In particular, the poverty rate continued to decline during the recent recession - because the median also fell (Figure 3). According to the relative poverty line definition, the UK poverty rate in 2012-13 was 15.4 per cent, corresponding to around 9.7 million poor people. 
Figure 7: Poverty rates (\%) since 1961: relative and anchored poverty lines

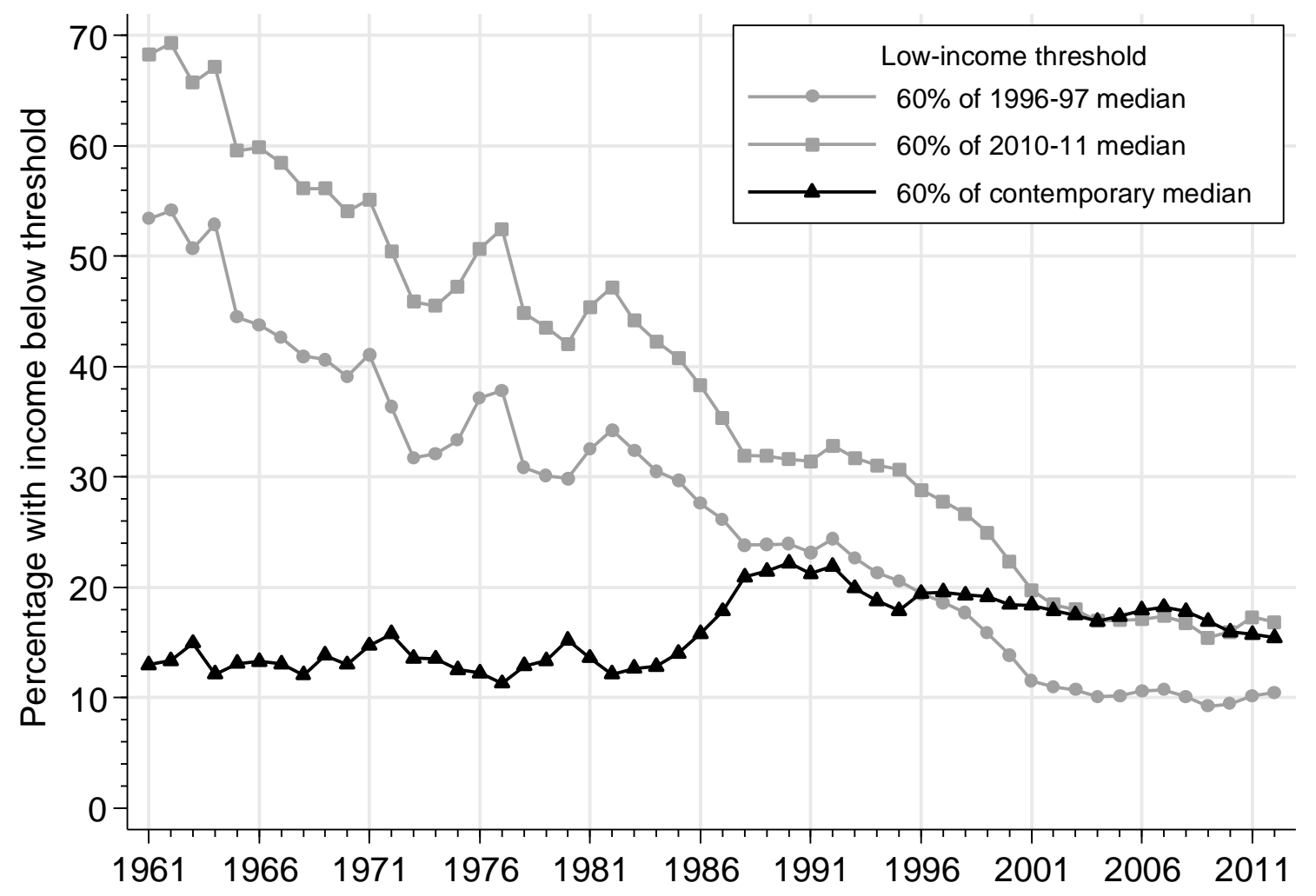

Notes: Graph drawn by the author using data from the spreadsheet accompanying Belfield et al. (2014) - see IFS (2014). The data refer to financial years from 1994 onwards, and the estimates to the UK from 2002-03 and Great Britain in earlier years. The BHC income definition is used (see text).

The poverty experience differs for particular subgroups. Of particular relevance for policy in recent years is child poverty and pensioner poverty. At the beginning of the 1990s, the child poverty rate was nearly 10 percentage points higher than the allpersons rate, but it has declined at a faster pace and was only two percentage points larger in 2012-13. The decline in pensioner poverty rates has been substantial, from around 40 per cent in the 1960s to the same as the all-persons rate in 2012-13, albeit with large increases and declines in between. See Appendix Figure A4 for details. For more extended discussion of long-run trends, see Cribb et al. (2013: chapter 5).

These estimates are based on a BHC income definition. If, instead, an AHC income definition is used, the picture of poverty levels and trends is different, especially since the 1990s. In 1990, the AHC relative poverty rate was 24 per cent (compared to a BHC rate of 21 per cent) but did not decline at the same rate thereafter. In 2012-13, the AHC relative poverty rate was 21 per cent (13.2 million people), i.e. around six percentage points greater than the BHC rate for that year. See Appendix Figure A5 for details. 
The BHC series based on anchored poverty lines show a substantial decline in poverty rates over the last five decades. For example, according to the relative poverty standards of the mid-1990s, more than half of the UK population was poor in the early 1960s, but only one-tenth five decades later. The rate of decline in both anchored series slows noticeably from around 2000 onwards - which is unsurprising given the slowing of income growth rates at the bottom of the distribution around that time (Figure 3). Observe as well and by contrast with the relative poverty series, that both anchored poverty series show a rise in the poverty rate with the recent recession (albeit a relatively small one).

The UK has a relative poverty rate two or three percentage points higher than the EU15 average from 1995 until around 2009 after which the rates converged: the UK rate declined (reflecting the falling UK median) and the EU-15 rate increased slightly. Again, using anchored poverty lines for each country (60 per cent of national medians in 2008) reveals a different picture for the post-recession period. In particular, both the UK and EU-15 poverty rates are estimated to increase by around two percentage points in the following four years, and so the differential is maintained. See Figure A6.

\section{The prevalence of affluence}

The prevalence of affluence can also be assessed in terms of relative and anchored thresholds and, again, the specific choice is somewhat arbitrary. I use twice the contemporary median, and a fixed real income threshold equal to $£ 1,000$ per week in 2012-13 prices.

Estimates using these two thresholds are shown in Figure 8, and derived from the same data that are used to compile the DWP's HBAI statistics. The proportion of persons with an income greater than twice the contemporary median has remained remarkably stable since the mid-1990s, at around 11 per cent. The figure also highlights substantial differences in the prevalence of affluence in London and the South East (a rate of around 17 per cent over the last two decades) with the its prevalence in the rest of the UK (a rate of around 8 per cent).

With the fixed £1,000-per-week threshold, the prevalence of affluence steadily increased, more than doubling from around 4 per cent in the mid-1990s to around 9 per cent in 2009, after which the rate fell by several percentage points. Again, individuals living in London and the South East had higher rates than those in the rest of the UK throughout the period, but the trends for each group mimicked the national picture. 
Figure 8: Percentages of individuals with an equivalised income greater than twice the contemporary median (dotted lines) or greater than £1000 per week (2012-13 prices) (solid lines)

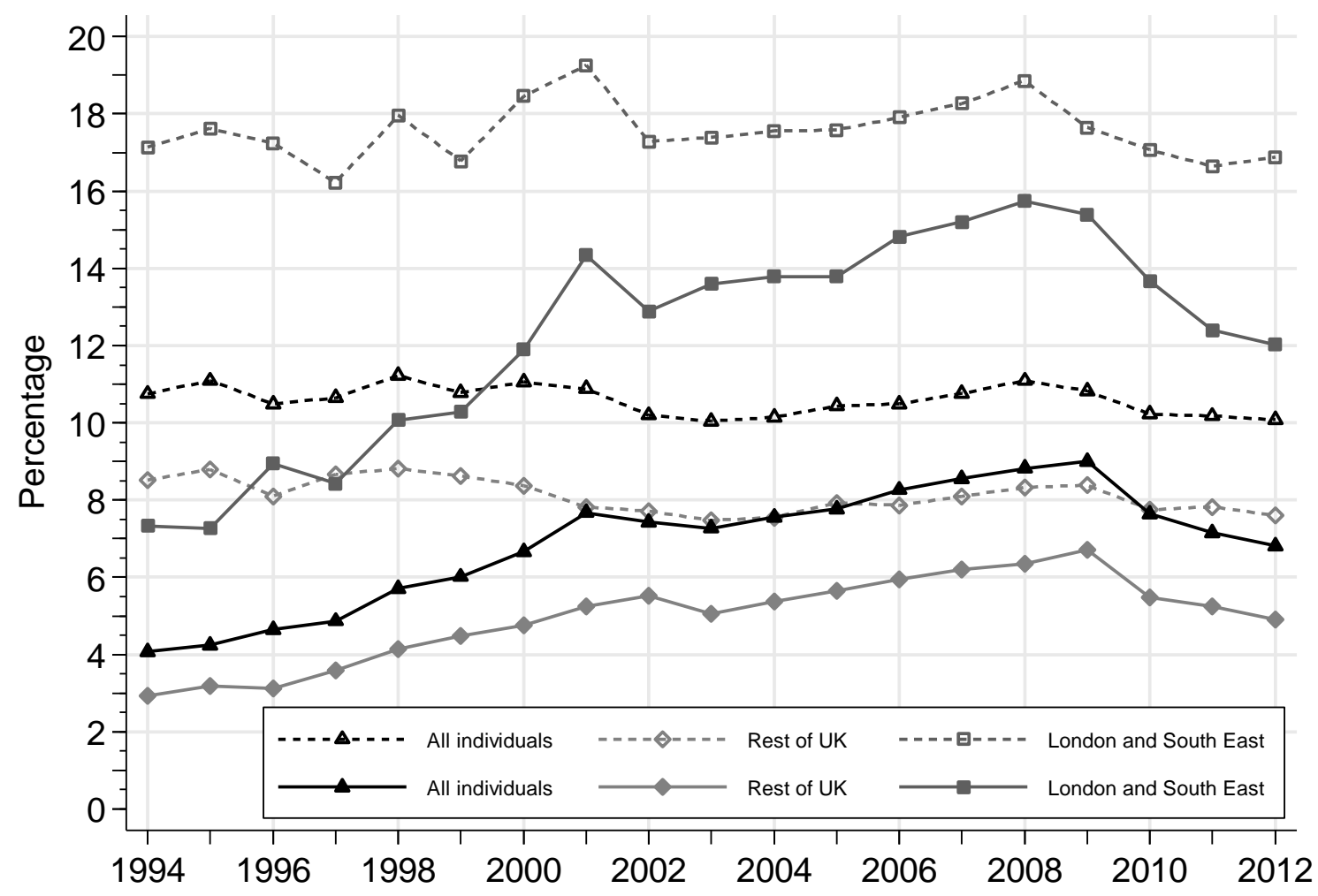

Notes: Graph drawn by the author using public-use files of HBAI unit record data accompanying DWP (2014a). The income definition is the same as the BHC definition used in Figures 1-4. The data refer to financial years from 1994 onwards, and the estimates to the UK from 2002-03 and Great Britain in earlier years.

The advantage of summaries such as Figure 8 is that they use the definitions routinely used to assess the income distribution in the UK. However, as discussed earlier, the coverage of top incomes in the underlying household survey data is not as good as income tax data on incomes.

Changes in the prevalence of affluence in the UK between 1995-96 and 2010-11 estimated from income tax data are summarised in Figure 9 using two absolute thresholds: $£ 500,000$ per year and $£ 1,000,000$ per year of after-tax income (in 201213 prices). By HBAI standards, an income above these cut-offs would place a person well into the top $1 \%$ of the income distribution. It is important to note, however, that these estimates refer to proportions of all taxpayers, not the population as a whole as in previous analysis, with most non-taxpayers having little or no income. (In 2010-11, there were around 31.3 million taxpayers, but the UK population was around 60 million.) 


\section{Figure 9: Percentages of taxpayers with an after-tax income greater than $£ 500,000$ and greater than $£ 1$ million pounds per year (2012-13 prices)}

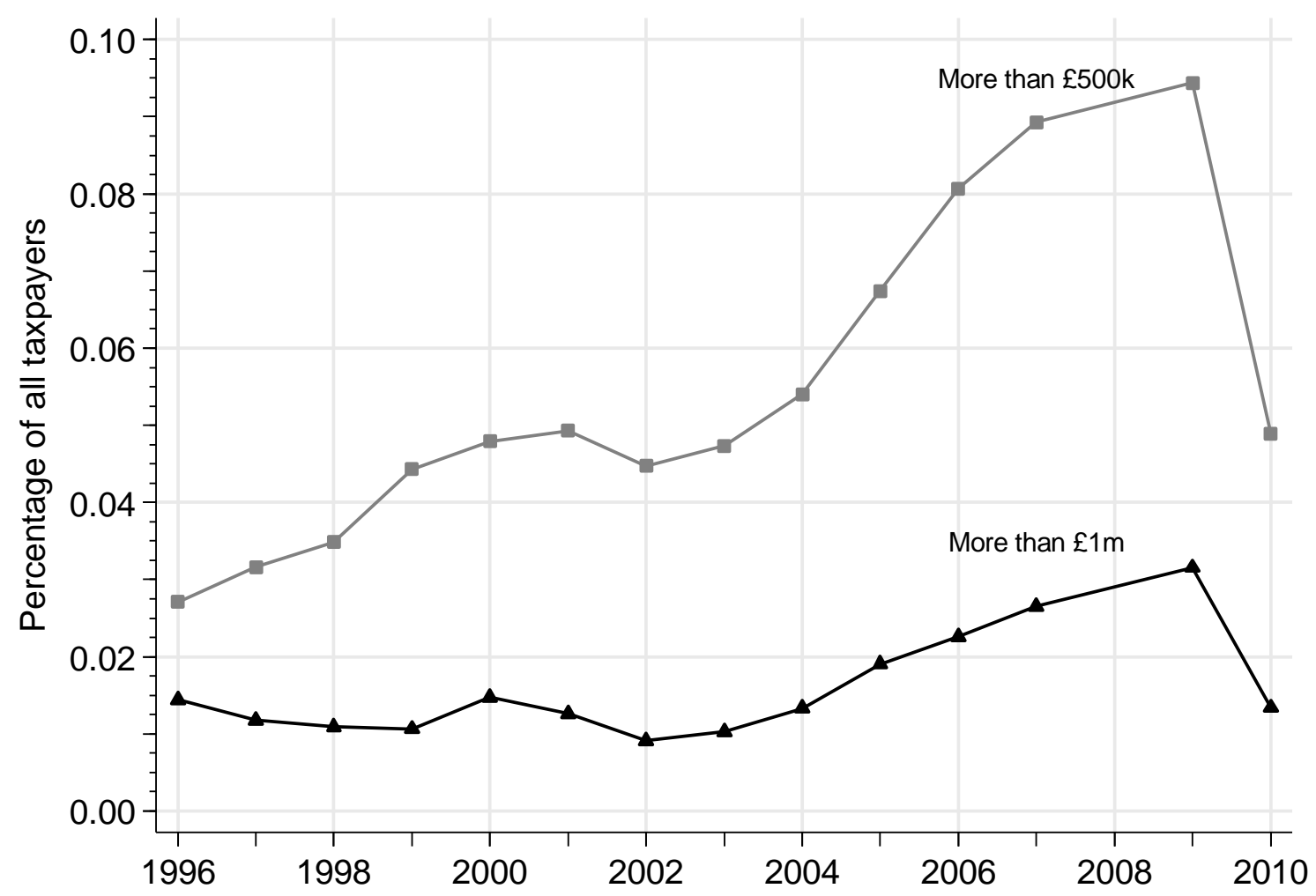

Notes: Years shown are financial years, e.g. 2010 refers to 2010-11. The data refer to taxpayers only, and are not available for 2008-09. Data for 1995-96 are not used because of a series discontinuity (introduction of self-assessment and changes to the SPI methodology). Graph drawn by the author using data from the public-use files of the Survey of Personal Incomes (various years). Incomes converted to 2012-13 prices using within-year averages of the monthly Consumer Price Index for each financial year.

Figure 9 shows that the proportion of taxpayers with an after-tax income of more than $£ 500$ million per year rose fivefold between the mid-1990s and the late-2000s, from around 0.02 per cent to nearly 0.10 per cent. The growth in the prevalence of taxpayers with an after-tax income of more than $£ 1$ million per year is more muted. The proportion remained at around 0.01 per cent from the mid-1990s until the early 2000s, but increased thereafter and by 2009-10 it was some three times higher. (The numbers of taxpayers involved is still only a few thousand.)

The marked rise in the prevalence of affluence appears to go into reverse after 200910, with both series showing much lower rates for 2010-11, with the fraction of millionaire taxpayers roughly halving for example. One obvious explanation for this reversal of fortunes is the recent recession. However, other more subtle changes mean that one has to be cautious about interpreting the 2010-11 estimates. In particular, a 50 per cent marginal rate of income tax was introduced in April 2010, and the announcement and introduction of this tax rate provided incentives for high income 
tax payers to bring forward income to 2009-10 that would otherwise have been reported in 2010-11 income tax returns or possibly later years.

This is the process of 'forestalling', discussed in more detail by HM Revenue and Customs (2012) and Cribb et al. (2012, 2013). Reverse forestalling in reaction to the reduction of the top marginal tax rate to 45 per cent (from April 2013) is also likely to affect reporting for later years. These issues make assessment of recent trends in the income distribution problematic for any summary measure that is calculated using top incomes, including the Gini inequality index (Cribb et al., 2013). However, the effects on the Gini (cf. Figure 4) are likely to be minor compared to their effects on estimates of the prevalence of affluence based on fixed real income thresholds as in Figure 7 and especially Figure 8.

The growth in affluence is shown for selected subgroups in Appendix Figure A7 using a threshold of $£ 100,000$ per year (2012-13 prices). The chart shows that such high after-tax incomes are much more prevalent among male taxpayers than female taxpayers, and among taxpayers in London and the South East than among all taxpayers. Prevalence rates rose for all groups between the mid-1990s and the onset of the late-2000s recession. Figure A7 also highlights the relatively large prevalence of high incomes among taxpayers working in the financial industry: in 1997-98 about $2^{1 / 2}$ per cent of this group had after-tax incomes over the $£ 100,000$ threshold; in 200910 , the proportion was 7 per cent.

For further discussion of top incomes through to the mid-2000s, the income tax data, and comparisons with HBAI series, see Brewer, Sibieta, and Wren-Lewis (2008). On recent trends in top wage income, see Bell and Van Reenen (2013).

\section{Income mobility and poverty dynamics}

The perspectives on distributional trends employed so far do not take account of the fact that someone who is poor in one year may be non-poor in the following year (or vice versa). Similarly, there is mobility into and out of middle- and top-income groups. The group of people that is poor - or rich - is not fixed over time.

Evidence about income mobility throughout the income range is displayed in Table 3. Individuals are classified by their quintile group origins in 2000 and their income group membership is tracked over the following eight years. The table shows that mobility is common but most of it is relatively short-distance. Only around oneseventh of individuals in the poorest fifth in 2000 remained in the poorest fifth in all nine years, though nearly one half spent all or the majority of years in that group. But this also means that 45 per cent spent the majority of years in the period in a higher income group. At first glance, downward mobility from the richest fifth in 2000 is less common than upward mobility from the poorest fifth, since just over a quarter of individuals with richest-fifth origins remained there all years, but around 40 per cent spent the majority of years in a lower income group. There is more scope for both 
upward and downward mobility for those starting in the middle: around two-thirds of those in the middle fifth in 2000 spent significant periods in a different income group.

Table 3: Where in the income distribution individuals spent the majority of their time over the nine-year period, 2000-2008

\begin{tabular}{lcrrrrr}
\hline & \multicolumn{5}{c}{ Quintile group in 2000 } \\
\cline { 2 - 6 } & $\begin{array}{l}\text { Bottom } \\
\text { (poorest) }\end{array}$ & Second & Third & Fourth & $\begin{array}{c}\text { Top } \\
\text { (richest) }\end{array}$ & $\begin{array}{c}\text { All } \\
\text { individuals }\end{array}$ \\
\hline $\begin{array}{l}\text { All years in the same quintile } \\
\text { group as 2000 }\end{array}$ & 14 & 3 & 2 & 4 & 26 & 10 \\
$\begin{array}{l}\text { Majority of years in same } \\
\text { quintile group as 2000 }\end{array}$ & 41 & 36 & 32 & 36 & 34 & 36 \\
$\begin{array}{l}\text { Majority of years above 2000 } \\
\text { quintile group }\end{array}$ & 45 & 31 & 25 & 16 & $\ldots$ & 23 \\
$\begin{array}{l}\text { Majority of years below } 2000 \\
\text { quintile group }\end{array}$ & $\ldots$ & 14 & 25 & 29 & 40 & 22 \\
$\begin{array}{l}\text { None of the above } \\
\text { All individuals }\end{array}$ & $\ldots$ & 17 & 15 & 16 & $\ldots$ & 9 \\
\hline
\end{tabular}

Notes: 'Majority of years in same quintile group' row: five or more years out of nine in the same quintile group as in base-year but does not include the individuals in the 'All years in same quintile' row. 'None of the above' implies that the individual has neither remained in the same quintile group as the base-year, nor been in a higher or lower quintile group for five of the nine years. '...': no estimate (not logically possible given definitions of groups). Source: Department for Work and Pensions (2010, Tables 3.2 (BHC) and 3.3 (BHC)), derived from British Household Panel Survey data. See Appendix Table A2 for corresponding estimates for the 1990s.

Despite the changes in the income distribution during the 1990s and 2000s shown earlier, the patterns of mobility were very similar in the two decades. See Appendix Table A3 which provides estimates for the two periods in the same format as Table 3. The no-change conclusion is also reported by Jenkins (2011) using an extensive portfolio of mobility measures.

The experience of poverty is likely to be more unpleasant the longer that it is experienced; thus, there is particular interest in the extent of poverty persistence. Information about its trends is provided by Figure 10. This shows the distribution of the number of times that individuals are poor within successive four-year periods. (The first calculation is for 1991-1994 and then the observation window is moved along a year at a time; the latest period is 2005-2008. The BHPS ended in 2008.) Using DWP (2010) definitions, an individual is persistently poor if he or she is poor three or four times in the four-year period. Figure 10 shows that since the mid-1990s, the persistent poverty rate has declined substantially, by around one-third from 15 per cent to nearly 10 per cent between the first four-year period and the one beginning in 2004. Over the same period, the number of people experiencing occasional poverty (one or two years poor in a four-year period) increased slightly over the same, and the proportion never poor increased from 65 per cent to 70 per cent. As the recession hit, 
however, the earlier trends reversed somewhat. For example, for the 2005-2008 period, the proportion persistently poor was around two percentage points larger than for the previous four-year period, and the proportion never poor fell by roughly the same amount.

The downward trend in persistent poverty prior to the late-2000s recession reflects improvements that are greatest for groups such as families with children, especially lone parent families, and also single pensioners. See Jenkins (2011: chapter 8) for details.

Figure 10: Percentages of individuals poor once, twice, or three or more times in a four-year period, by year

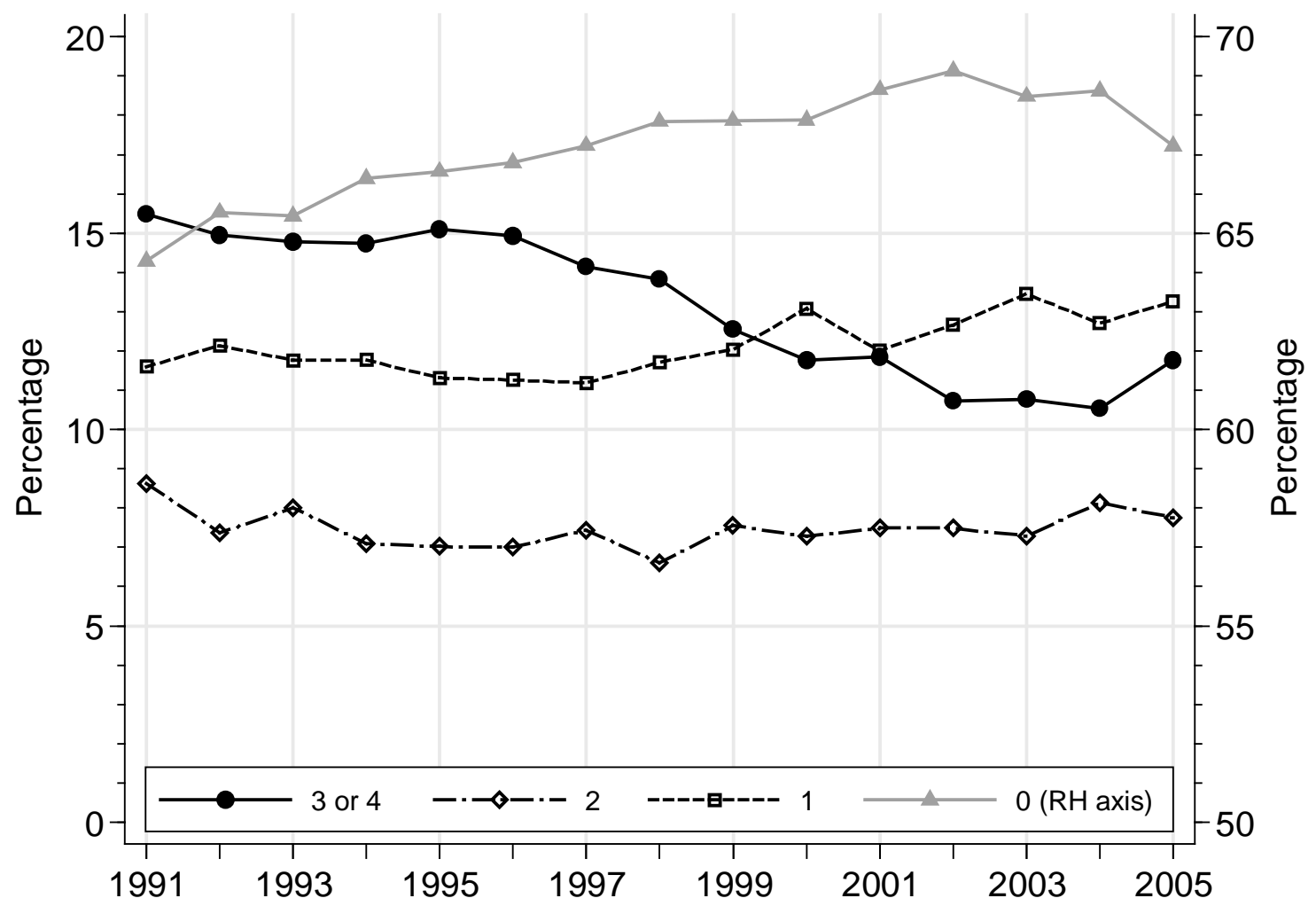

Notes: Author's calculations from British Household Panel Survey data (Levy and Jenkins, 2012). Year labels refer to the first year of each four-year period, e.g. '1991' refers to the years 1991-1994. The poverty line for each year is $60 \%$ of median net household income (BHC). Poverty counts refer to poverty status around the date of the annual BHPS interview.

\section{Concluding remarks}

Although social policy has often treated poverty as the main feature of the income distribution of interest, recent distributional trends in the UK suggest that other features demand as much attention and analysis. This paper has drawn attention to the stagnation in real income growth for those at the bottom while at the same time 
incomes at the top have been growing, particularly at the very top. The distributional issues for the UK of contemporary concern are as much the growth in the prevalence of advantage rather than disadvantage - growing inequality as much as poverty.

The reasons why the growth in inequality is an important social issue nowadays are threefold: there are views that the higher incomes were not fairly achieved, that greater income inequality is associated with greater inequalities in many other spheres, and that greater inequality may have deleterious consequences for economic growth.

The relationship between inequality and economic growth has long been controversial but recent research concludes that, among OECD countries, 'when income inequality rises, economic growth falls. One reason is that poorer members of society are less able to invest in their education. Tackling inequality can make our societies fairer and our economies stronger' (OECD, 2014: 1). Others have emphasised that stagnation in incomes at the bottom has been accompanied by unsustainable growth in household debt that may have led to the recent financial crisis or at least hindered recovery from it. For a review of evidence, see Lucchino and Morelli (2012).

There is a growing literature arguing that income inequality growth is harmful because it weakens the fabric of our society and social cohesion in its broadest sense. The fabric is represented by a shared experience of a common education system, health service, and pensions, as well as fundamental democratic principles such as oneperson one-vote and equality before the law. The problem is that the very rich may increasingly opt out of, or be less willing to contribute to, the collective pot that finances benefits and services, or deploy their resources to secure outcomes that are favourable to their own interests via politics, media, or the law. To date, the literature on this topic has mostly been about the USA, no doubt reflecting the fact that inequality levels and inequality growth have been greater there than in the UK. (See, for example, Bartels (2008), Hacker and Pierson (2010), and Stiglitz (2012).) Given the distributional trends in the UK that have been described in this paper, analysis of their consequences is an important topic for analysis on this side of the Atlantic as well. Extensive discussion of what can be done about economic inequality is provided by Atkinson (2015). 


\section{References}

Alvaredo, F., Atkinson, A.B., Piketty, T., and Saez, E. (2014). The World Top Incomes Database, online database. http://topincomes.gmond.parisschoolofeconomics.eu/ (accessed 14 October 2014).

Atkinson, A.B. (2015). Inequality: What Can Be Done? Cambridge, MA: Harvard University Press, forthcoming.

Atkinson, A.B., Piketty, T., and Saez, E. (2011). 'Top incomes in the long run of history', Journal of Economic Literature, 49(1): 3-71.

Bartels, L.M. (2008). Unequal Democracy. The Political Economy of the New Gilded Age. Princeton, NJ: Princeton University Press.

Bell, B. and Van Reenen, J. (2013). Extreme wage inequality: pay at the very top', American Economic Review, Papers and Proceedings, 103(3): 153-157.

Belfield, C., Cribb, J., Hood, A., and Joyce, R. (2014). Living standards, poverty and inequality in the UK: 2014. Report R96. London: Institute for Fiscal Studies. http://www.ifs.org.uk/publications/7274

Brewer, M. and O'Dea, C. (2012). Measuring living standards with income and consumption: evidence from the UK. Working Paper W12/12. London: Institute for Fiscal Studies. http://www.ifs.org.uk/wps/wp1212.pdf

Brewer, M., Sibieta, L., and Wren-Lewis, S. (2008). Racing away? Income inequality and the evolution of high incomes. Briefing Note 76. London: Institute for Fiscal Studies. http://www.ifs.org.uk/bns/bn76.pdf

Brewer, M., O’Dea, C., Paull, G. and Sibieta, L. (2009). The Living Standards of Families with Children Reporting Low Incomes. DWP Research Report No 577. London: Department for Work and Pensions. http://eprints.ucl.ac.uk/18312/1/18312.pdf

Council of the European Union (2004). Joint report by the Commission and the Council on Social Inclusion. Brussels. Council of the European Union. http://ec.europa.eu/employment_social/soc-prot/socincl/final_joint_inclusion_report_2003_en.pdf

Cribb, J., Joyce, R., and Philip, D. (2012). Living Standards, Poverty and Inequality in the UK: 2012. Commentary C214. London: Institute for Fiscal Studies. http://www.ifs.org.uk/comms/comm124.pdf

Cribb, J., Hood, A., Joyce, R., and Phillips, D. (2013). Living Standards, Poverty and Inequality in the UK: 2013. Report R81. London: Institute for Fiscal Studies. http://www.ifs.org.uk/comms/r81.pdf.

Department for Work and Pensions (2010). Low Income Dynamics. London: Department for Work and Pensions. https://www.gov.uk/government/publications/low-income-dynamics-1991-to1998 
Department for Work and Pensions (2014a). Households Below Average Income 1994/5-2012/13. London: Department for Work and Pensions. https://www.gov.uk/government/collections/households-below-averageincome-hbai--2.

Department for Work and Pensions (2014b). Quality and Methodology Information Report. London: Department for Work and Pensions. https://www.gov.uk/government/collections/households-below-averageincome-hbai--2.

Eurostat (2014). Online statistical database.

http://epp.eurostat.ec.europa.eu/portal/page/portal/statistics/search_database (accessed 19 October 2014).

Expert Group on Household Income Statistics (The Canberra Group) (2001). Final Report and Recommendations. Ottawa: Statistics Canada. http://www.lisdatacenter.org/books/the-canberra-group-expert-group-onhousehold-income-statistics-final-report-and-recommendations/

Flower, T. and Wales, P. (2014). Variation in the inflation experience of UK households: 2003 - 2014. London: Office for National Statistics. http://www.ons.gov.uk/ons/guide-method/user-guidance/prices/cpi-andrpi/variation-in-the-inflation-experience-of-uk-households--2003-2014.pdf

Gregg, P., Machin, S., and Fernández-Salgado, M. (2014). 'The squeeze on real wages - and what it might take to end it', National Institute Economic Review, 228, R3-R16.

Hacker, J. S. and Pierson, P. (2010). Winner-Take-All Politics: How Washington Made the Rich Richer - and Turned its Back on the Middle Class. New York: Simon and Schuster.

HM Revenue and Customs (2012). The Exchequer effect of the 50 per cent additional rate of income tax. London: HMRC.

Institute for Fiscal Studies (IFS) (2014). Inequality and poverty spreadsheet. London: Institute for Fiscal Studies. www.ifs.org.uk/bns/bn19figs.xlsx

Jenkins, S. P. (1991). 'Poverty measurement and the within-household distribution: agenda for action', Journal of Social Policy, 20(4), 457-483.

Jenkins, S. P. (2011). Changing Fortunes: Income Mobility and Poverty Dynamics in Britain. Oxford: Oxford University Press.

Jenkins, S. P., Brandolini, A., Micklewright, J., and Nolan, B. (eds) (2013). The Great Recession and the Distribution of Household Income. Oxford: Oxford University Press, Oxford.

Johnson, P. and Webb, S. (1992). 'The treatment of housing in official low income statistics', Journal of the Royal Statistical Society. Series A, 155(2), 273-290.

Levy, H. and Jenkins, S. P. (2012). 'Derived net current and annual income variables to accompany BHPS waves 1-18'. Study SN3909. Colchester: UK Data Service. 
Lucchino, P. and Morelli, S. (2012). Inequality, Debt and Growth. London: Resolution Foundation. http://www.resolutionfoundation.org/wpcontent/uploads/2014/08/Final-Inequality-debt-and-growth.pdf

National Equality Panel (J. Hills, Chair). (2010). An Anatomy of Economic Inequality in the UK. Report of the National Equality Panel. London: Government Inequalities Office. http://eprints.lse.ac.uk/28344/1/CASEreport60.pdf

OECD (2014). Focus on inequality and growth - December 2014. Paris: OECD. http://www.oecd.org/els/soc/Focus-Inequality-and-Growth-2014.pdf

Stiglitz, J.E. (2012). The Price of Inequality. How Today's Divided Society Endangers Our Future. London: Allen Lane. 


\section{Appendix}

Table A1: Real income growth rates (\%), by subperiod

\begin{tabular}{cccccccc}
\hline & $1961-2012$ & $1961-71$ & $1971-81$ & $1981-91$ & $1991-2001$ & $2001-11$ & $2007-12$ \\
\hline$p 10$ & 89.2 & 14.4 & 18.0 & 6.2 & 28.5 & 3.8 & 0.9 \\
& $(1.3)$ & $(1.4)$ & $(1.7)$ & $(0.6)$ & $(2.5)$ & $(0.4)$ & $(0.2)$ \\
p50 & 97.4 & 14.8 & 12.4 & 27.9 & 20.5 & -0.6 & -4.5 \\
& $(1.3)$ & $(1.4)$ & $(1.2)$ & $(2.5)$ & $(1.9)$ & $(-0.1)$ & $(-0.9)$ \\
p90 & 129.6 & 16.9 & 16.6 & 45.6 & 19.2 & -2.3 & -6.2 \\
& $(1.6)$ & $(1.6)$ & $(1.6)$ & $(3.8)$ & $(1.8)$ & $(-0.2)$ & $(-1.3)$ \\
\multirow{2}{*}{ Mean } & 117.3 & 15.8 & 13.1 & 37.5 & 22.9 & -0.2 & -6.2 \\
& $(1.5)$ & $(1.5)$ & $(1.2)$ & $(3.2)$ & $(2.1)$ & $(-0.0)$ & $(-1.3)$ \\
\hline
\end{tabular}

Notes: Author's calculations using data from IFS (2014). p10, p50, and p90 are the 10th percentile, 50th percentile (median), and 90th percentile, respectively. The numbers in parentheses for each period are annualised growth rates per annum. The data refer to financial years from 1994 onwards, and the estimates refer to the UK from 2002-03 and Great Britain in earlier years. 
Table A2: Where in the income distribution individuals spent the majority of their time over nine-year periods, 1991-1999 and 2000-2008

\begin{tabular}{|c|c|c|c|c|c|c|}
\hline & \multicolumn{6}{|c|}{ Quintile group in 1991} \\
\hline & $\begin{array}{l}\text { Bottom } \\
\text { (poorest) }\end{array}$ & Second & Third & Fourth & $\begin{array}{c}\text { Top } \\
\text { (richest) }\end{array}$ & $\begin{array}{c}\text { All } \\
\text { individuals }\end{array}$ \\
\hline $\begin{array}{l}\text { All years in the same quintile } \\
\text { group as } 1991\end{array}$ & 14 & 3 & 2 & 3 & 24 & 9 \\
\hline $\begin{array}{l}\text { Majority of years in same } \\
\text { quintile group as } 1991\end{array}$ & 43 & 36 & 34 & 39 & 39 & 38 \\
\hline $\begin{array}{l}\text { Majority of years above } 1991 \\
\text { quintile group }\end{array}$ & 43 & 31 & 24 & 15 & $\ldots$ & 23 \\
\hline $\begin{array}{l}\text { Majority of years below } 1991 \\
\text { quintile group }\end{array}$ & $\cdots$ & 15 & 25 & 30 & 37 & 21 \\
\hline None of the above & $\ldots$ & 14 & 15 & 13 & $\ldots$ & 8 \\
\hline \multirow[t]{2}{*}{ All individuals } & 100 & 100 & 100 & 100 & 100 & 100 \\
\hline & \multicolumn{6}{|c|}{ Quintile group in 2000} \\
\hline $\begin{array}{l}\text { All years in the same quintile } \\
\text { group as } 2000\end{array}$ & 14 & 3 & 2 & 4 & 26 & 10 \\
\hline $\begin{array}{l}\text { Majority of years in same } \\
\text { quintile group as } 2000\end{array}$ & 41 & 36 & 32 & 36 & 34 & 36 \\
\hline $\begin{array}{l}\text { Majority of years above } 2000 \\
\text { quintile group }\end{array}$ & 45 & 31 & 25 & 16 & $\cdots$ & 23 \\
\hline $\begin{array}{l}\text { Majority of years below } 2000 \\
\text { quintile group }\end{array}$ & $\cdots$ & 14 & 25 & 29 & 40 & 22 \\
\hline None of the above & $\ldots$ & 17 & 15 & 16 & $\ldots$ & 9 \\
\hline All individuals & 100 & 100 & 100 & 100 & 100 & 100 \\
\hline
\end{tabular}

Notes: Source is Department for Work and Pensions (2010, Tables 3.2 (BHC) and 3.3 (BHC)), derived from British Household Panel Survey data. 'Majority of years in same quintile group' row: five or more years out of nine in the same quintile group as in base-year but does not include the individuals in the 'All years in same quintile' row. 'None of the above' implies that the individual has neither remained in the same quintile group as the base-year, nor been in a higher or lower quintile group for five of the nine years. '...': no estimate (not logically possible given definitions of groups). 
Figure A1: The Gini coefficient since 1961: BHC and AHC series compared

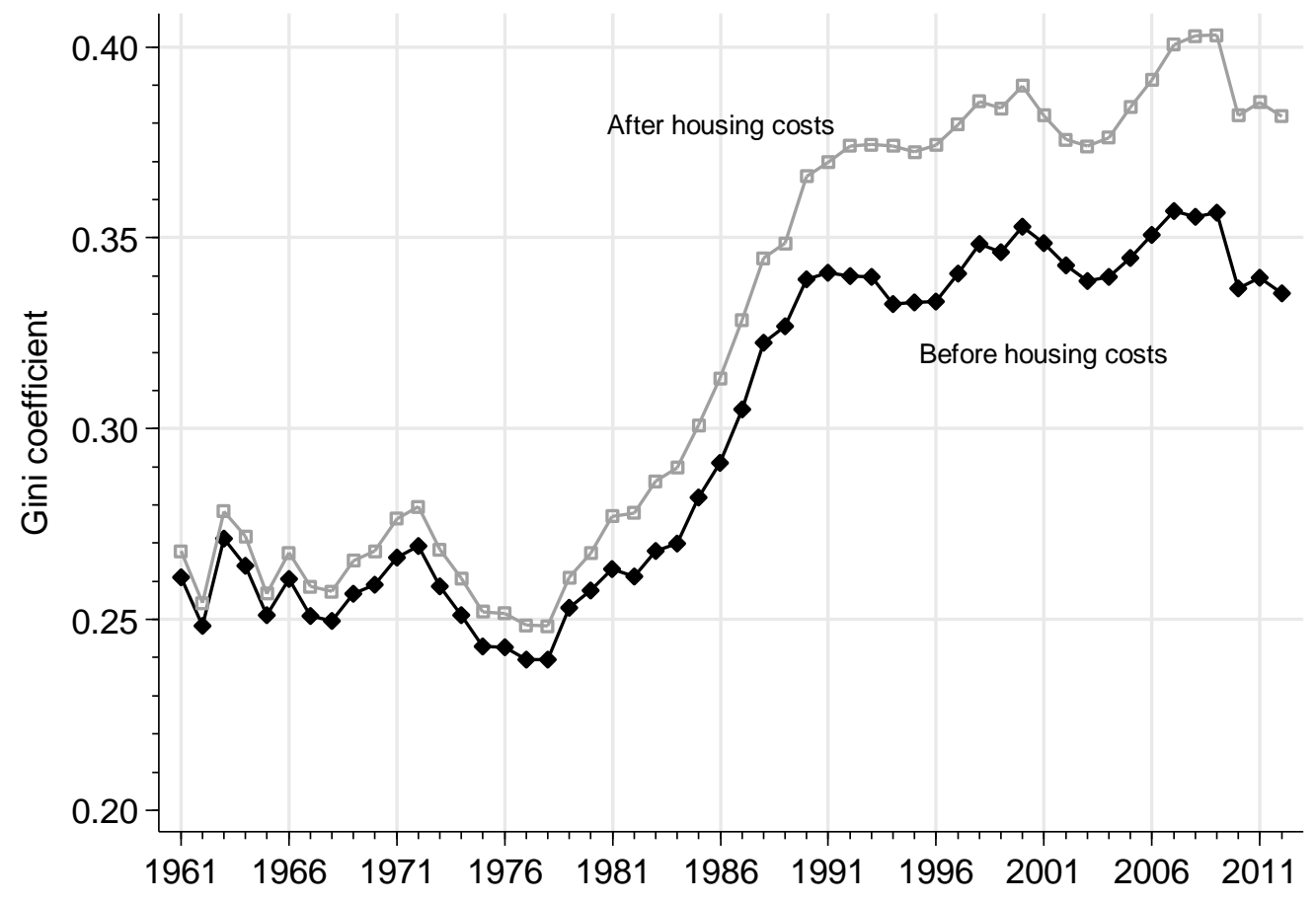

Notes: Graph drawn by the author using data from IFS (2014).

Figure A2: Trends in the Gini coefficient: the UK compared to the EU-15 average

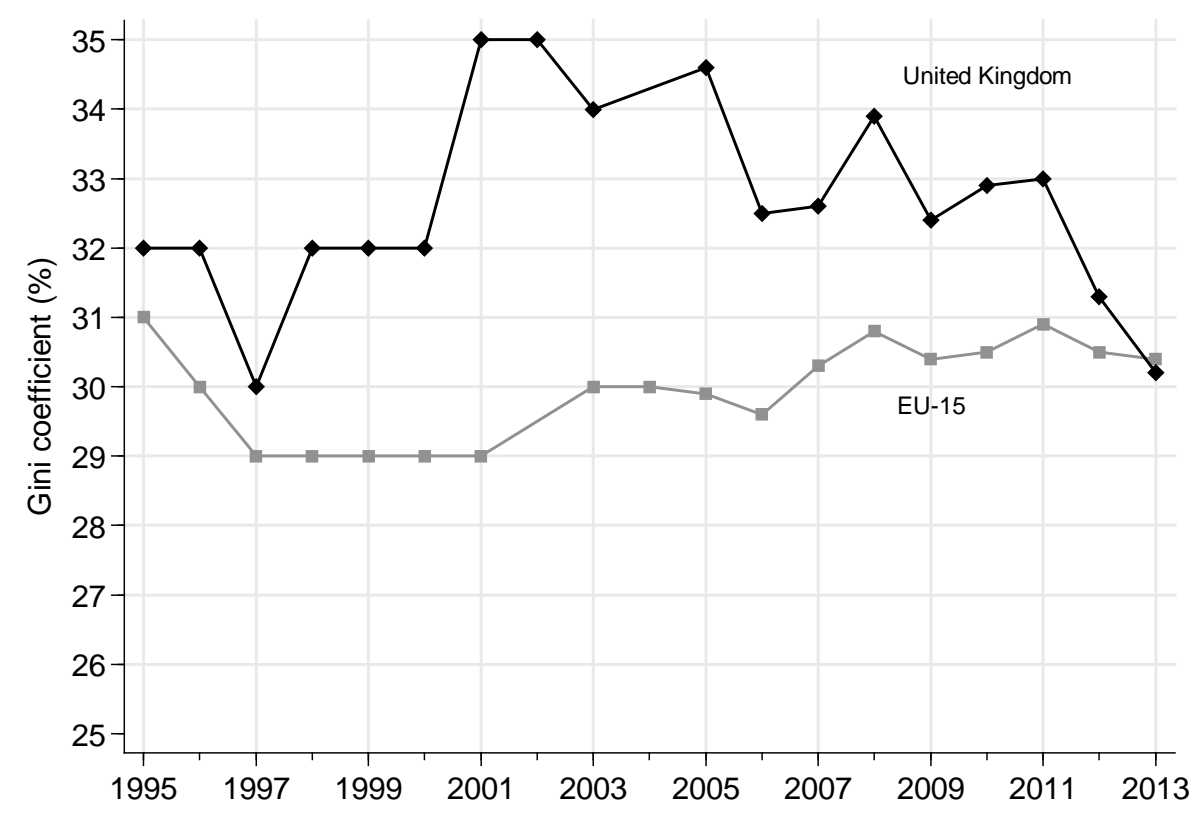

Notes: Graph drawn by the author using EU-SILC-based estimates reported in Eurostat (2014, series ilc_di12). The EU-15 estimates are population-weighted averages of estimates for national member states. 
Figure A3: Share of total income held by the top 1\%: UK, France, Germany, and the USA

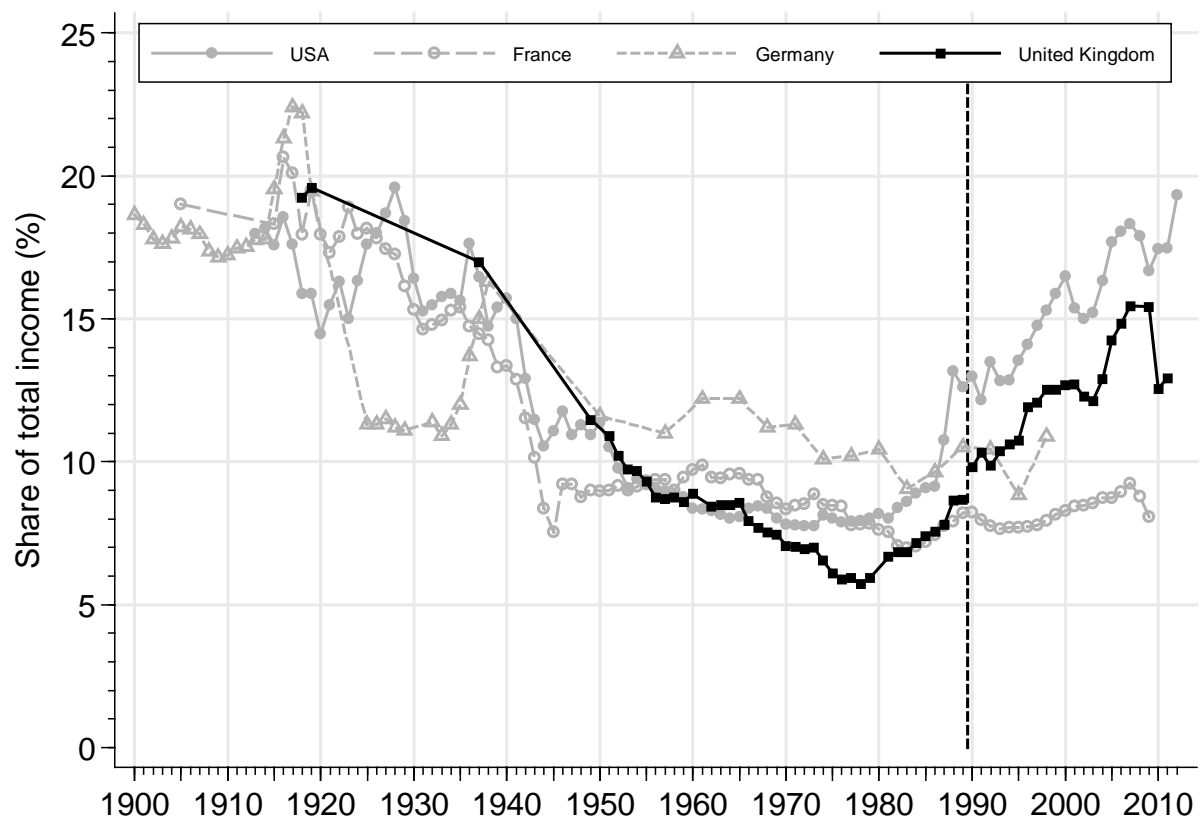

Notes: Graph drawn by the author using data from the World Top Incomes Database (Alvaredo et al., 2014). The vertical dashed line marks the change in the definition of the tax unit from the family to the individual in the UK in 1990.

Figure A4: Proportions of persons with income below $60 \%$ of contemporary median income (BHC): all individuals, children, and pensioners, 1961-2012

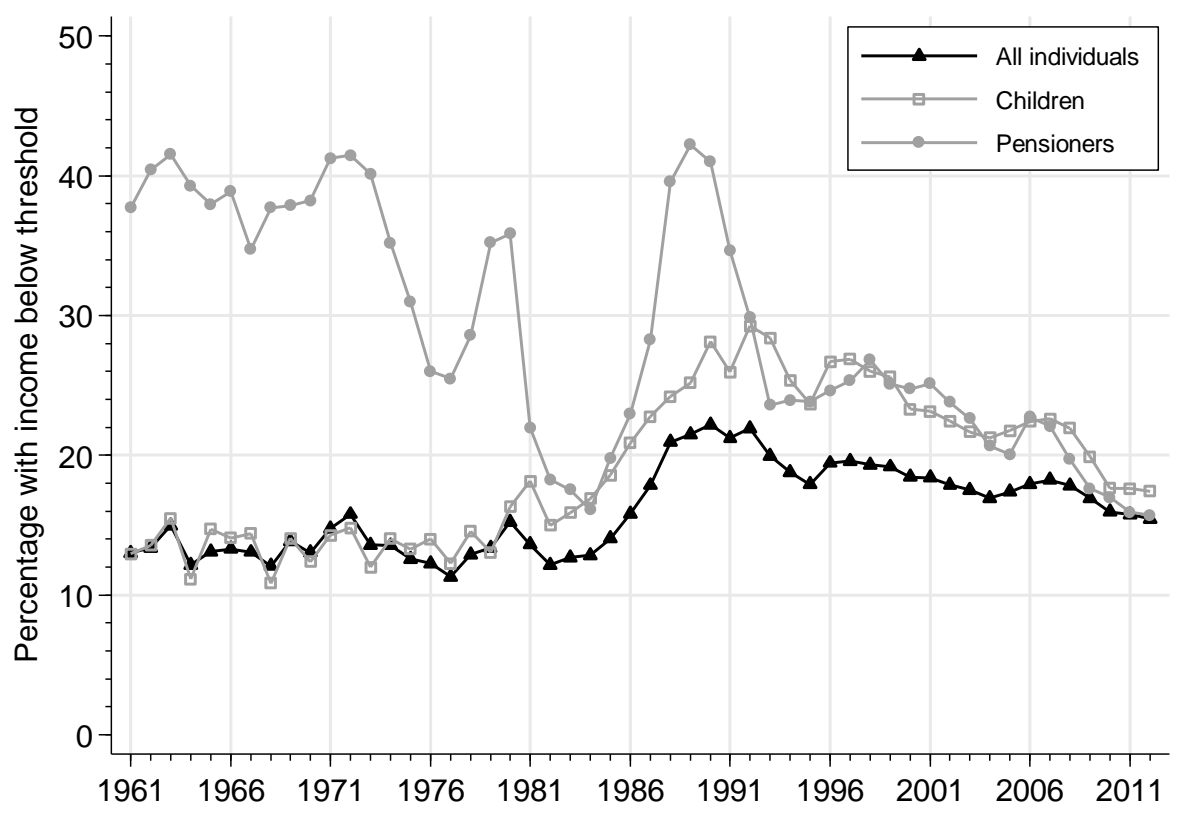

Notes: Graph drawn by the author using data from IFS (2014). The data refer to financial years from 1994 onwards, and the estimates to the UK from 2002-03 and Great Britain in earlier years. 
Figure A5: Proportions of persons with income below $60 \%$ median: BHC vs AHC series compared

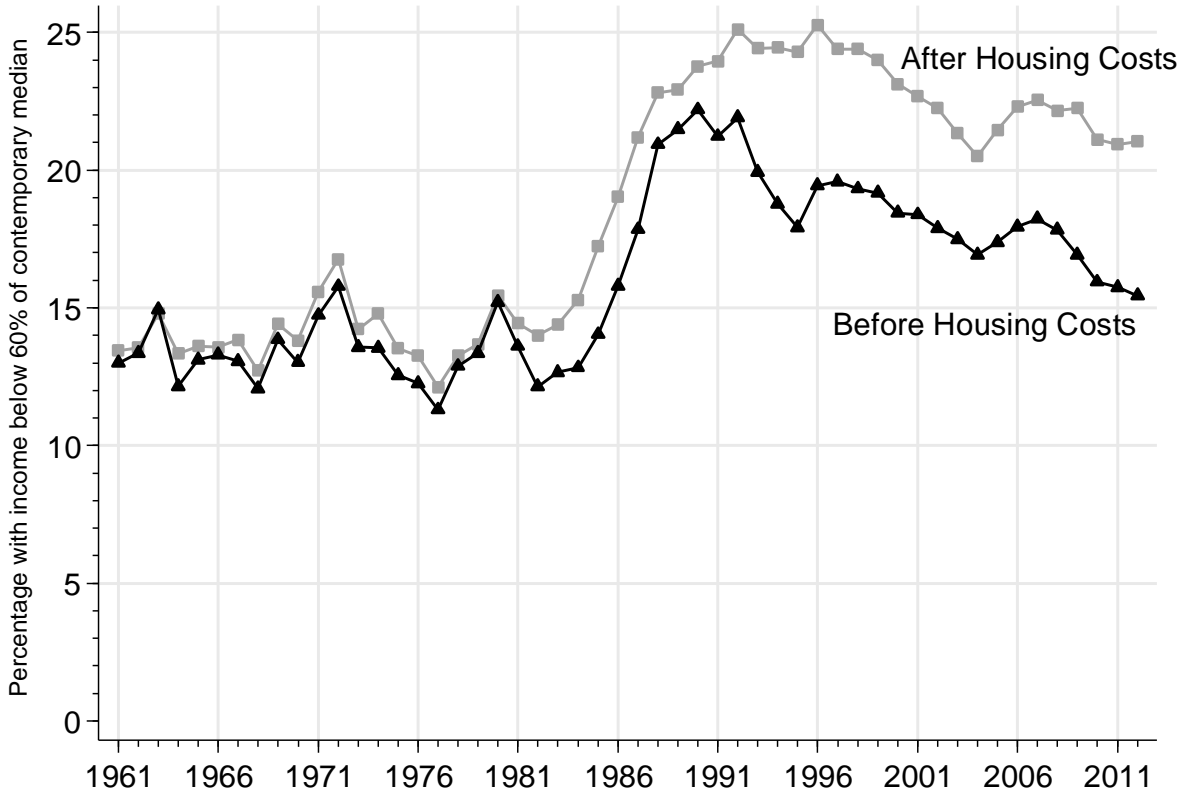

Notes: Graph drawn by the author using data from IFS (2014). The data refer to financial years from 1994 onwards, and the estimates to the UK from 2002-03 and Great Britain in earlier years.

Figure A6: Poverty rates (\%) using relative and anchored thresholds: UK and EU-15 average

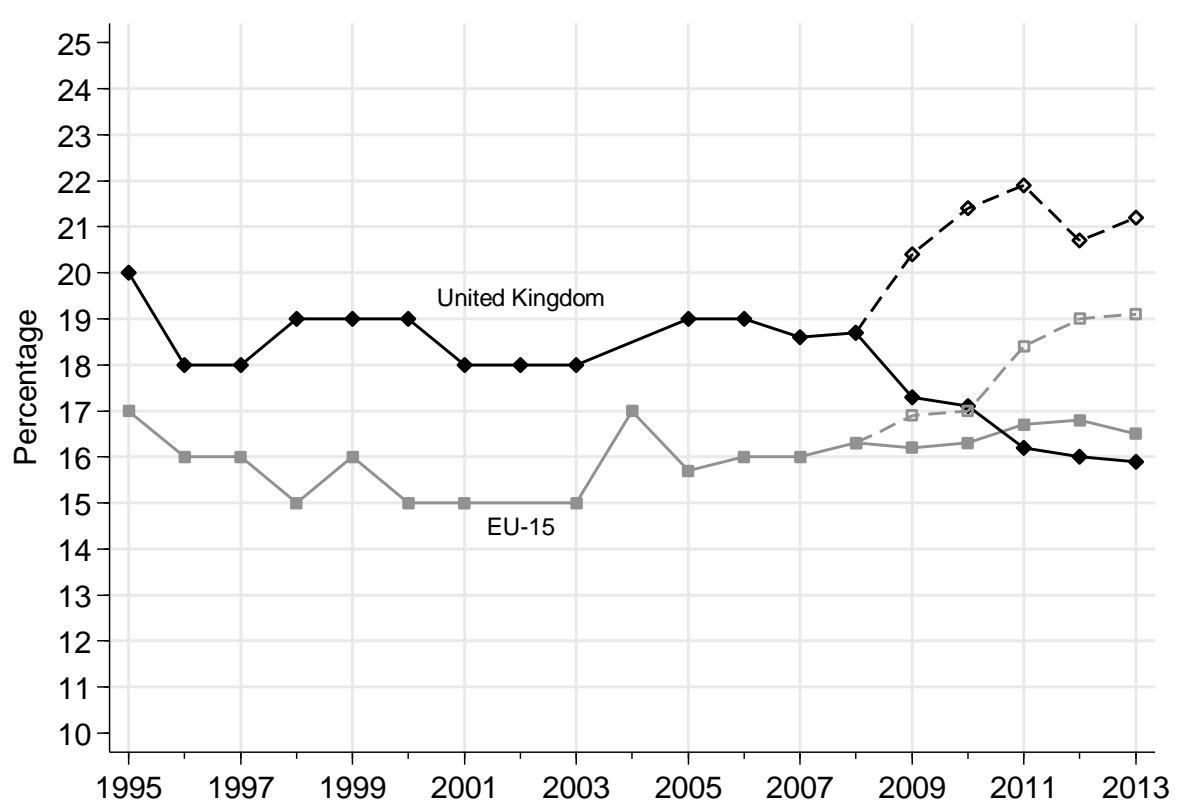

Notes: Graph drawn by author using EU-SILC-based estimates reported in Eurostat (2014, series ilc_li02 and ilc_li22b). The solid lines show poverty rates calculated using a relative threshold (60\% of contemporary national median income); the dashed lines show poverty rates calculated using an anchored threshold (60\% of national median income in 2008). Estimates of anchored poverty rates are available only from 2008 onwards. 
Figure A7: Percentages of taxpayers with an after-tax income greater than $£ 100,000$ per year (2012-13 prices), by subgroup

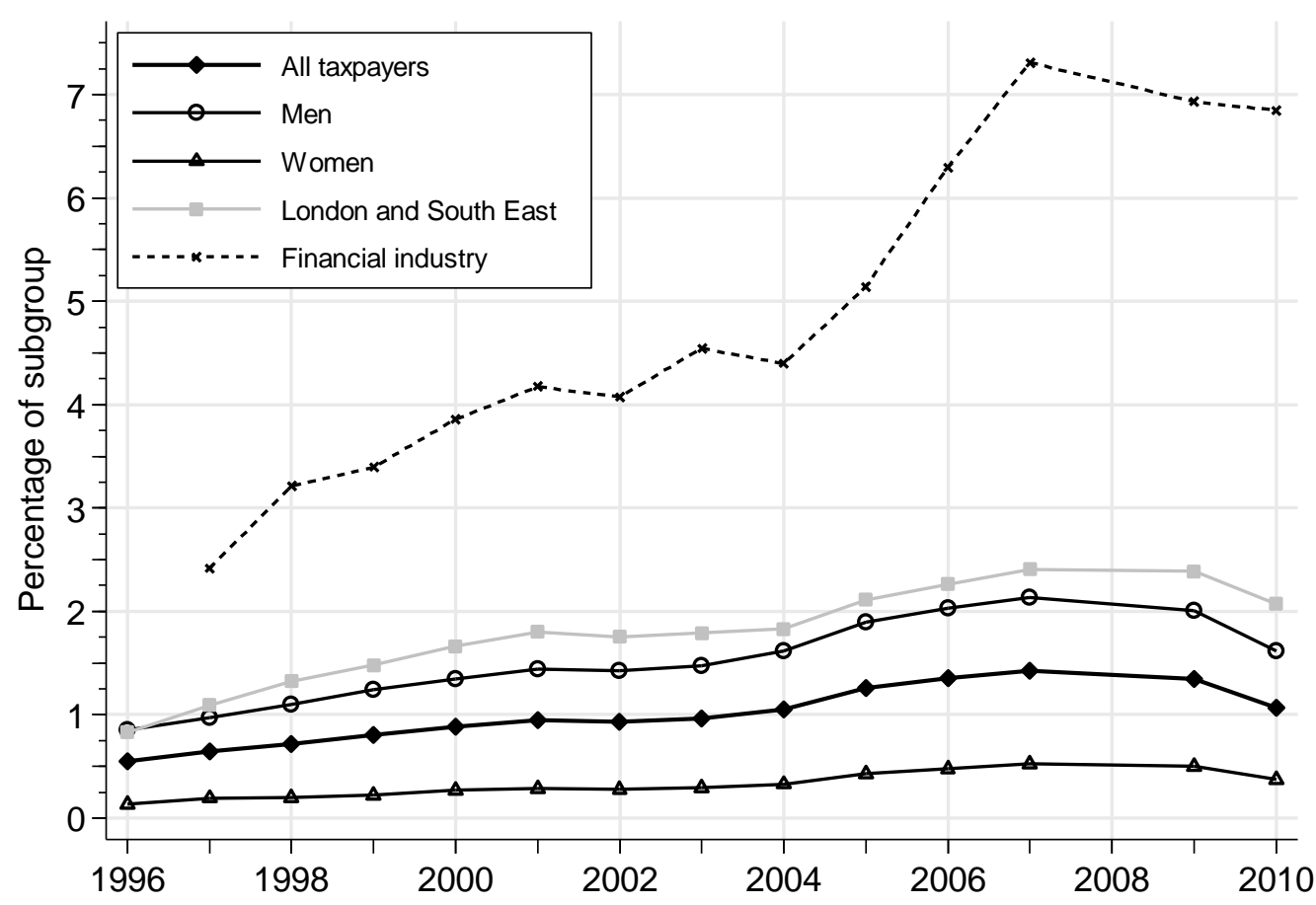

Notes: Years shown are financial years, e.g. 2010 refers to 2010-11. The data refer to taxpayers only, and are not available for 2008-09. Data for 1995-96 are not used because of a series discontinuity (introduction of self-assessment and changes to the SPI methodology). Graph drawn by the author using data from the public-use files of the Survey of Personal Incomes (various years). Incomes converted to 2012-13 prices using within-year averages of the monthly Consumer Price Index for each financial year. Reading note: $7 \%$ of taxpayers working in the financial industry had an after-tax income of more than $£ 100,000$ in financial year 2009-10. 